\title{
The Disappearing Colorado River: Historic and Modern Attempts to Manage the Lifeline of the United States Southwest
}

\author{
Kenneth R. Olson ${ }^{*}{ }^{\circledR}$, James M. Lang ${ }^{2}$ \\ ${ }^{1}$ Department of Natural Resources, Urbana, Illinois, USA \\ ${ }^{2}$ Department of Crop Sciences, College of Agricultural, Consumer, and Environmental Sciences, University of Illinois, \\ Urbana, Illinois, USA \\ Email: *krolson@illinois.edu
}

How to cite this paper: Olson, K.R. and Lang, J.M. (2021) The Disappearing Colorado River: Historic and Modern Attempts to Manage the Lifeline of the United States Southwest. Open Journal of Soil Science, 11, 538-566.

https://doi.org/10.4236/ojss.2021.1111027

Received: October 23, 2021

Accepted: November 21, 2021

Published: November 24, 2021

Copyright $\odot 2021$ by author(s) and Scientific Research Publishing Inc. This work is licensed under the Creative Commons Attribution International License (CC BY 4.0).

http://creativecommons.org/licenses/by/4.0/

\begin{abstract}
Historic Native American and modern civilizations have been forcing the unstable use of the Colorado River and adjacent land resources for centuries. Much can be learned from past Native American cultures that created irrigation systems to offset low rainfall. These lessons learned can be applied to our modern civilization. We can learn a lot from their previous behavior and experiences and could apply the lessons learned to our current disappearing Colorado River situation. Little of the Colorado River water flow reaches the international border with Mexico near Yuma, Arizona. Intensive consumption, mostly in the United States, has dried up the lower $160 \mathrm{~km}$ of the river. Since the 1960s, the Colorado River has rarely flowed into the Gulf of California and when it does it becomes is a major international news event. The Colorado River Delta is drought prone and its headwater tributaries are a vital source of water for 40 million people. The Colorado River has whitewater rapids, canyons, and many United States National Parks. The tributary and river flow is managed by an extensive system of dams, aqueducts, and reservoirs. Most years the entire Colorado River flow is used for United States agricultural irrigation and domestic water supply purposes. The agricultural and urban needs in the United States are continuing to grow and it appears the days of Colorado River flowing into Mexico and the Gulf of California are numbered and declining every decade. The Colorado River is disappearing and restoration efforts appear to be too little too late. If the Colorado River valley is ever going to recover management lessons and failures learned from the Native Americans, including the Hohokam, must be applied. A balanced approach to water management is needed and must include aggressive conservation and efficiency measures.
\end{abstract}




\section{Keywords}

Grand Canyon, Hohokam, Mexico-American War, Gulf of California, Salton Trough, Hoover Dam, Glen Canyon Dam

\section{Introduction}

The Colorado River headwaters start in the southern Rocky Mountains of Colorado at La Poudre Pass and the river flows through the Grand Canyon and into Lake Mead. The river then turns south into Mexico where it historically flowed towards the tip of the Gulf of California. The Colorado River includes parts of 7 states-Wyoming, Utah, New Mexico, Colorado, Arizona, Nevada and California. The Colorado is $2330 \mathrm{~km}$ long and drains a $637,137 \mathrm{~km}^{2}$ basin. For $27 \mathrm{~km}$, the river is the international boundary between the United States (Arizona) and Mexico (Figure 1) [1]. The river is often referred to as the "Lifeline of the South West". It flows through and drains a vast arid and semiarid section of North America. The Colorado River had cut a two kilometer deep canyon known as the Grand Canyon. The Grand Canyon is one of the Seven Natural Wonders of the World (Figures 2-6). Each Colorado tributary river, such as the Little Colorado River (Figure 7) and (Figure 8) draining into the Colorado River had cut narrow deep canyons making the Colorado basin a labyrinth of deep gorges. The longest of the unbroken trunk canyon is the Grand Canyon extending from the Grand Wash Stream to the mouth of Praia. The Marble, Glen and Cataract canyons were cut by the river flow.

Further downstream, the Colorado passes by the Mojave and Sonoran deserts (Figure 9). Part of the Sonoran Desert including Yuma and Colorado deserts lies in the Salton Trough (Figure 10). The trough is an enormous structural depression which extends northwest from head of the Gulf of California (Figure 1), a distance of $240 \mathrm{~km}$. At one time, the Gulf extended further northwest to a point above where the Colorado currently enters the filled-in Salton Trough [1].

In 1905, floodwaters caused a break in Imperial Canal diversion controls. As a result, the Colorado River flowed into Salton Sink, creating the Salton Sea (Figure 10). The total surface area was $777 \mathrm{~km}^{2}$ and about $21 \mathrm{~m}$ deep, $80 \mathrm{~km}$ long and 16 to $24 \mathrm{~km}$ wide. The breach threatened and inundated the agriculturally rich Imperial Valley and blocked a main railroad route. The repaired railroad breach in 1907 completed a line of protective levees. Today, the Salton Sea acts as a receiving wastewater basin from irrigation projects in the Coachella and Imperial valleys. These valleys received Colorado River water via the All-American Canal.

Water projects now go through environmental impact studies [2]. Controversy between the United States and Mexico was addressed in 1972 agreement. The United States lead a desalinization experiment in the Lower Colorado River Basin and irrigation management projects set the world standard [3] for the disposal of saline water in the upper basin. 
The primary objectives are to study: 1) the historical layers of soils, sediments and water flows under ancient climates, 2) the Hohokam culture's land and water management experiences on the Salt, Gila and Lower Colorado rivers and 3)

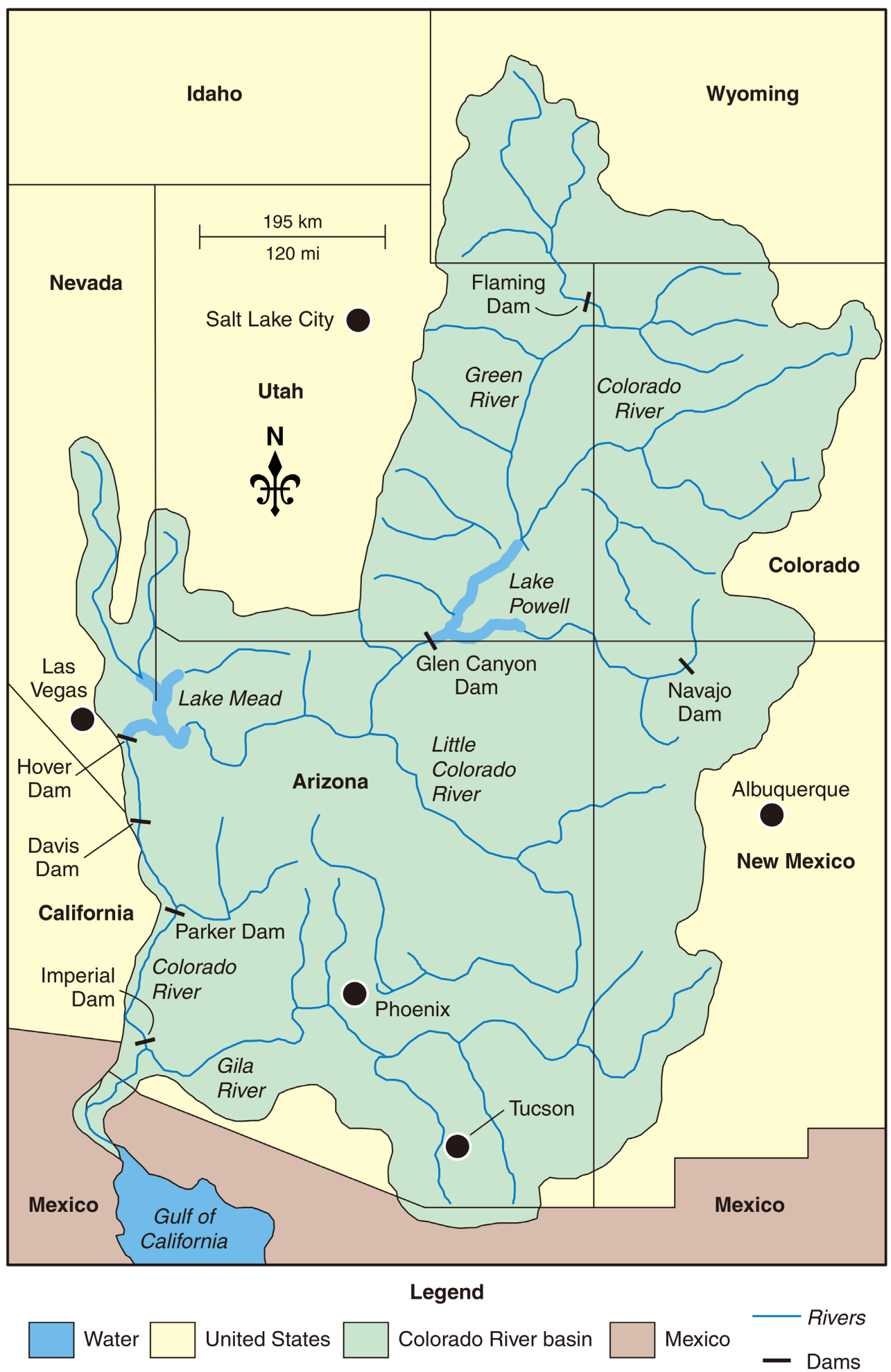

Figure 1. Colorado watershed in United States and Mexico. The Colorado which drains into the Gulf of California. 


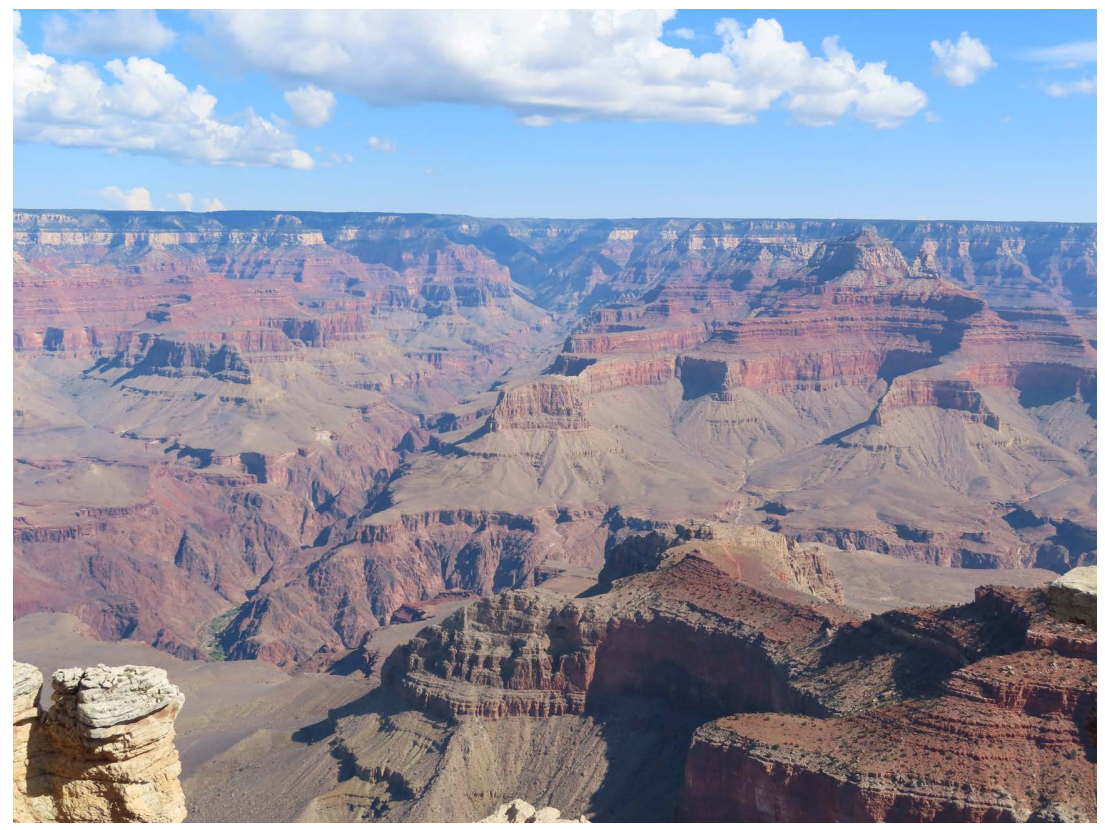

Figure 2. Grand Canyon and Colorado River.

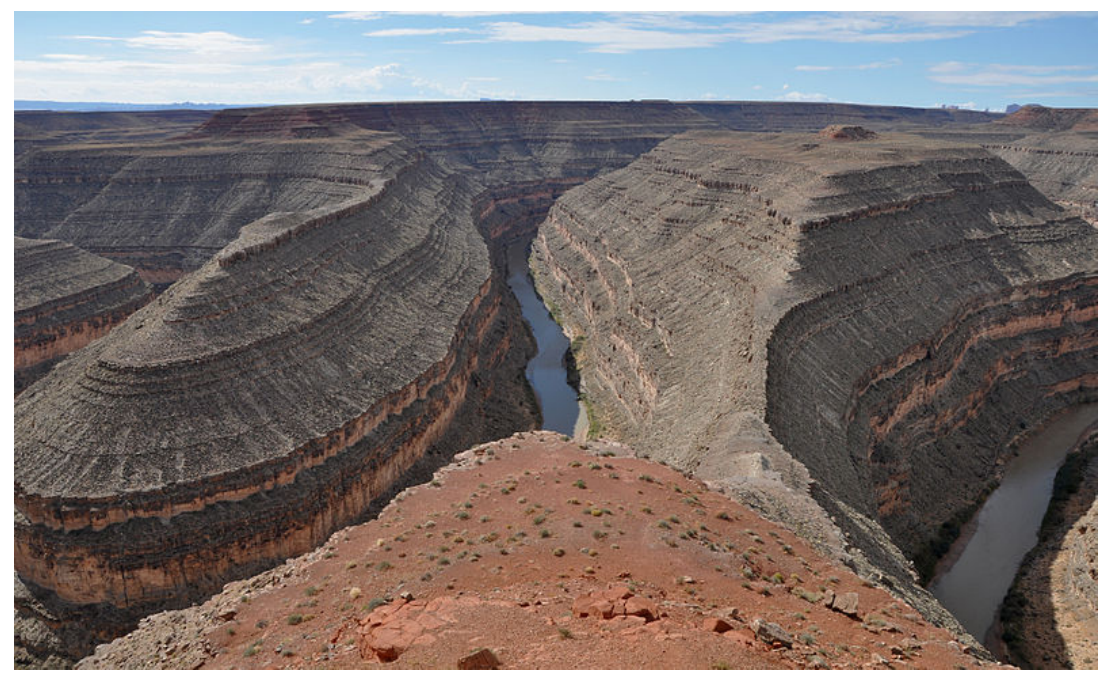

Figure 3. Horseshoe Bends in Arizona.

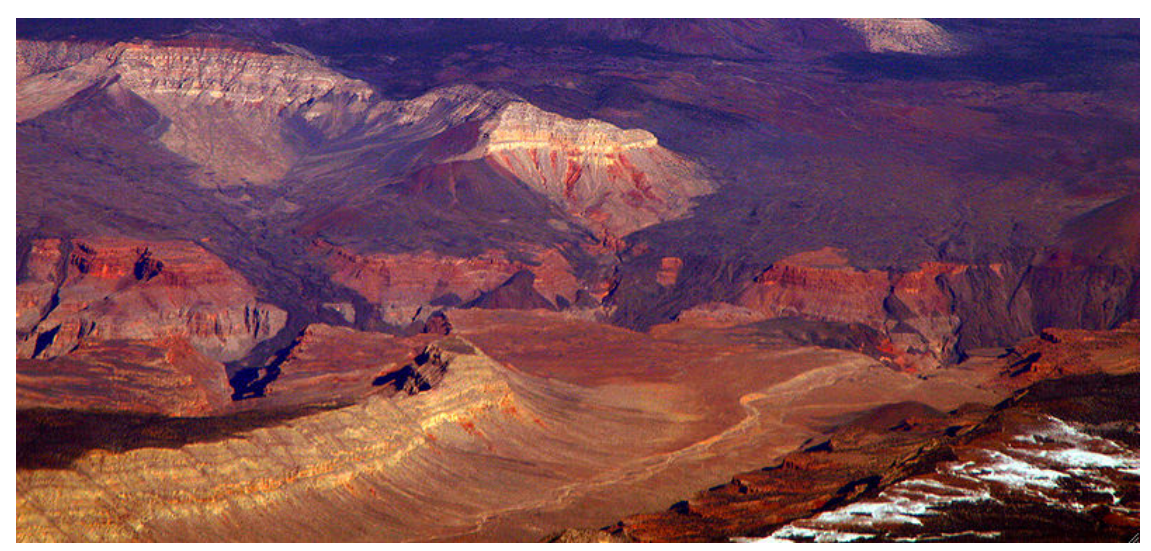

Figure 4. Lava flows into Grand Canyon watershed. 


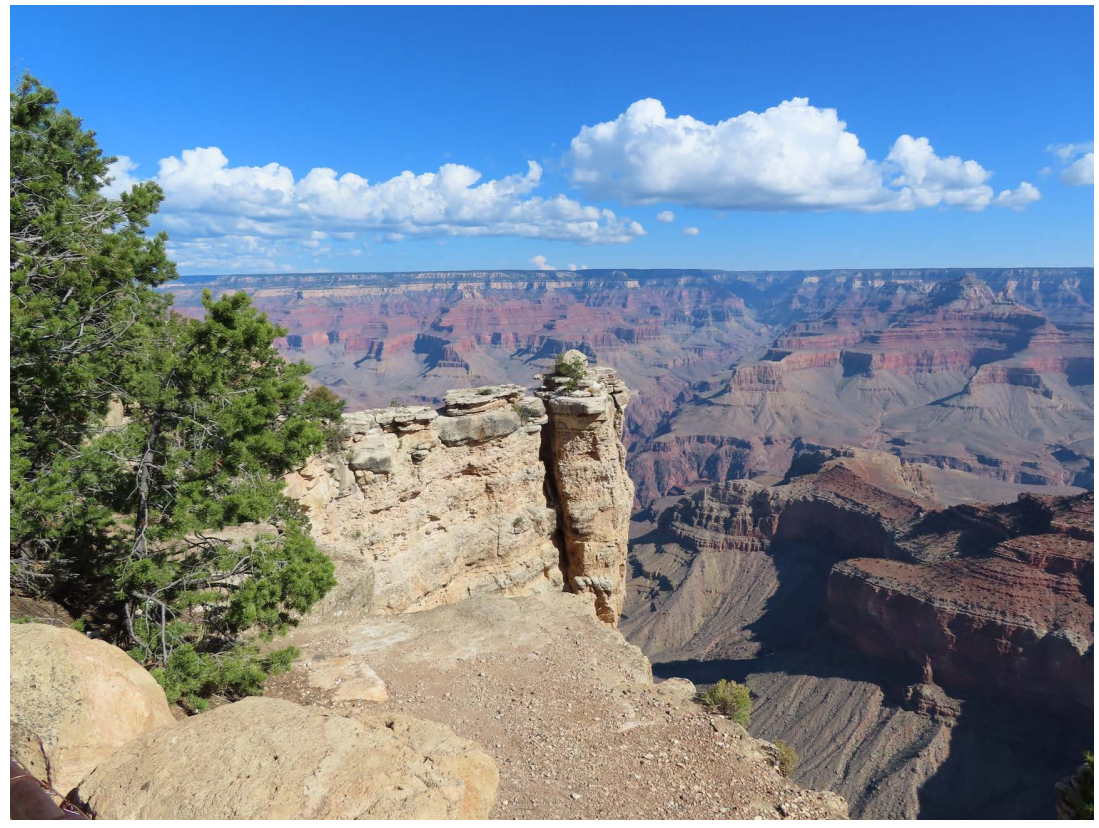

Figure 5. Different colored bedrocks in the Grand Canyon sidewalls.

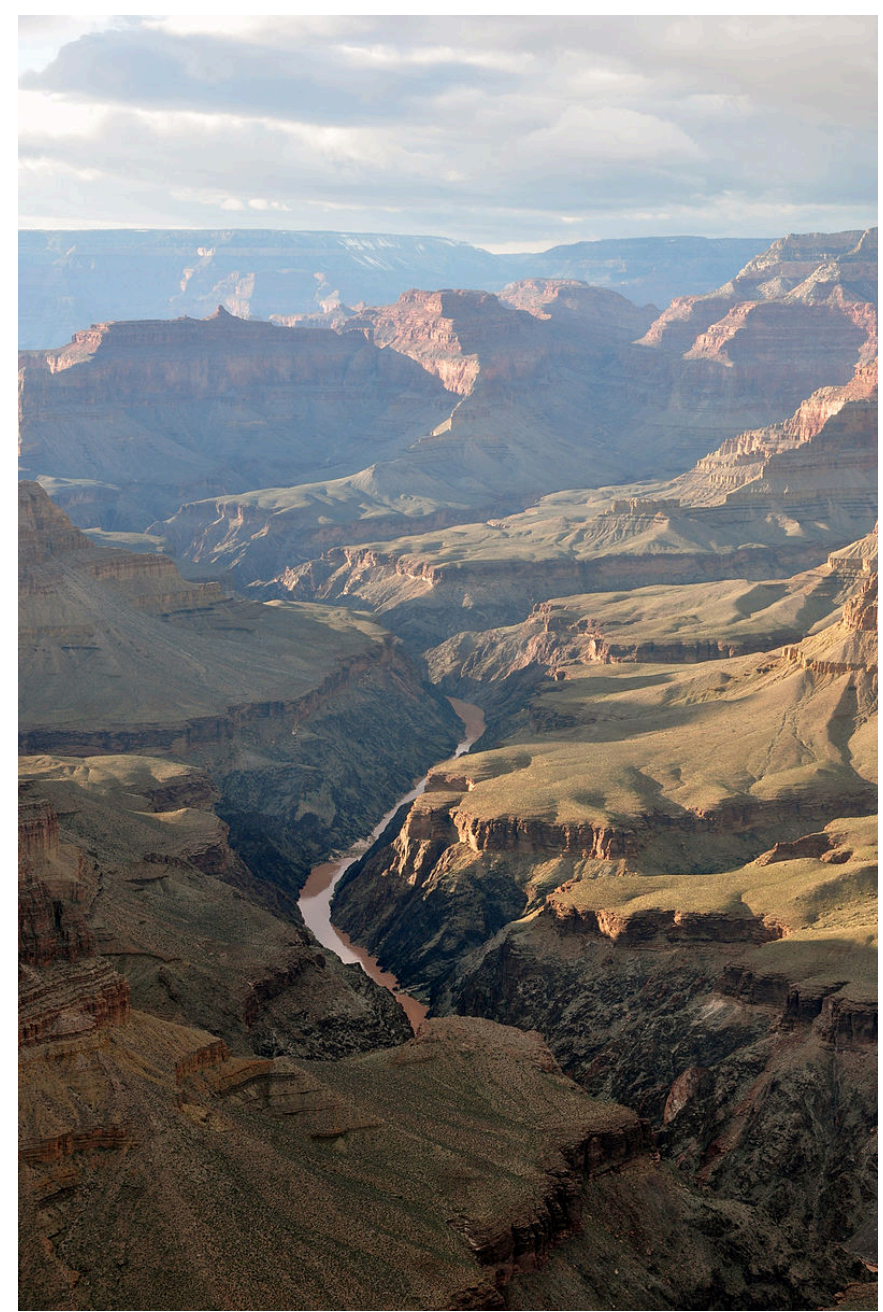

Figure 6. Colorado River as it flows through the Grand Canyon area. 


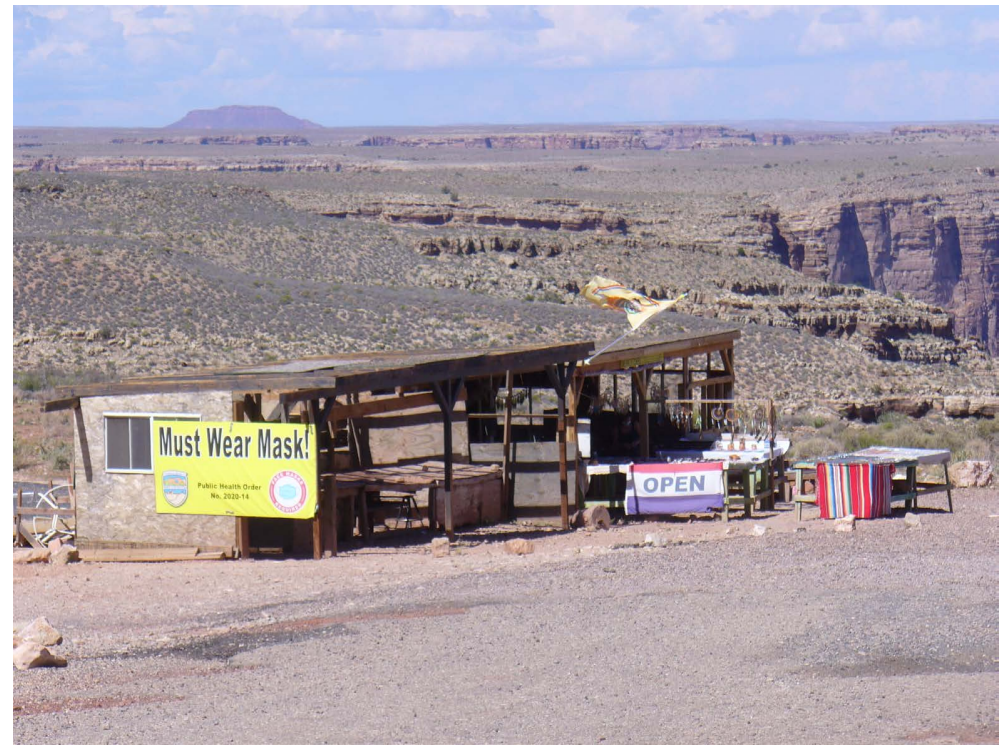

Figure 7. Native Americans selling artifacts at a rest stop near the Little Colorado River canyon.

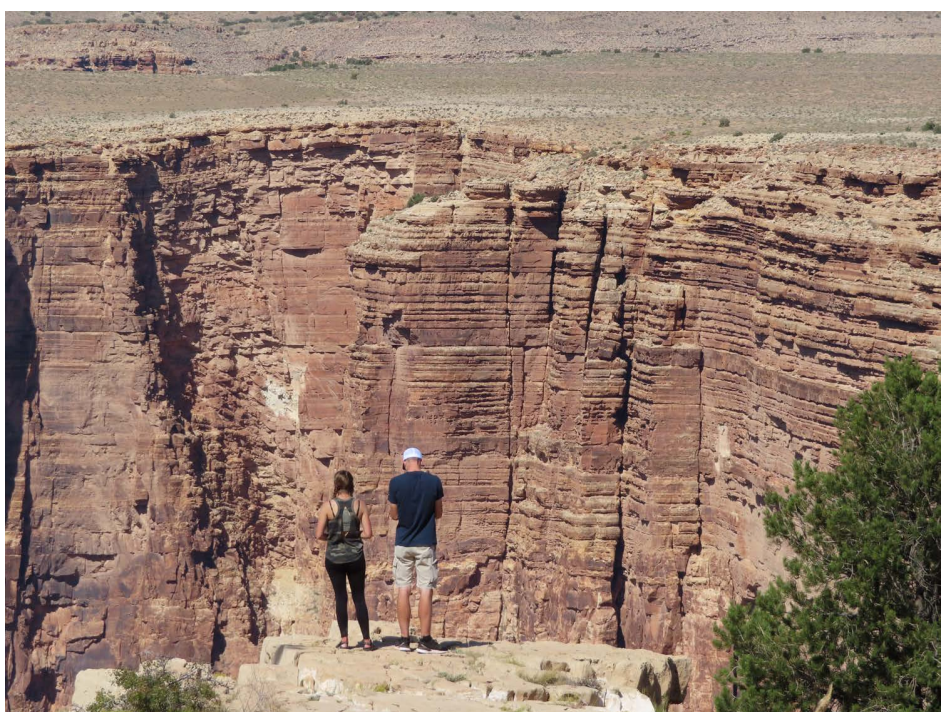

Figure 8. A vista on the Little Colorado River canyon.

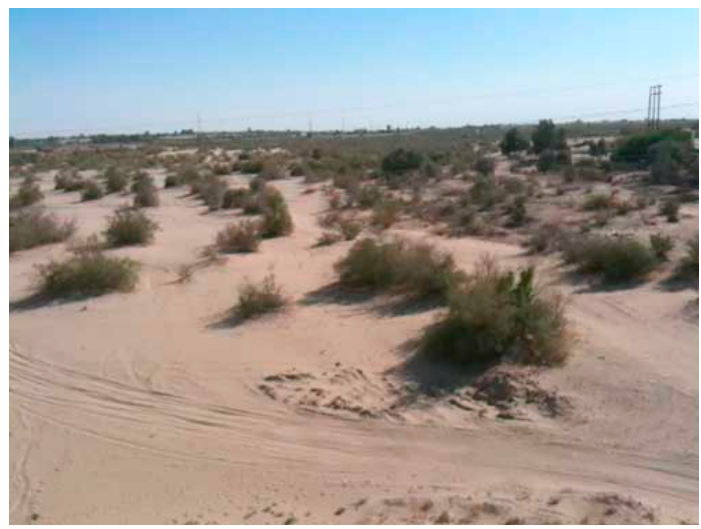

Figure 9. The dried up sandy river bed of the Colorado River tributaries. 


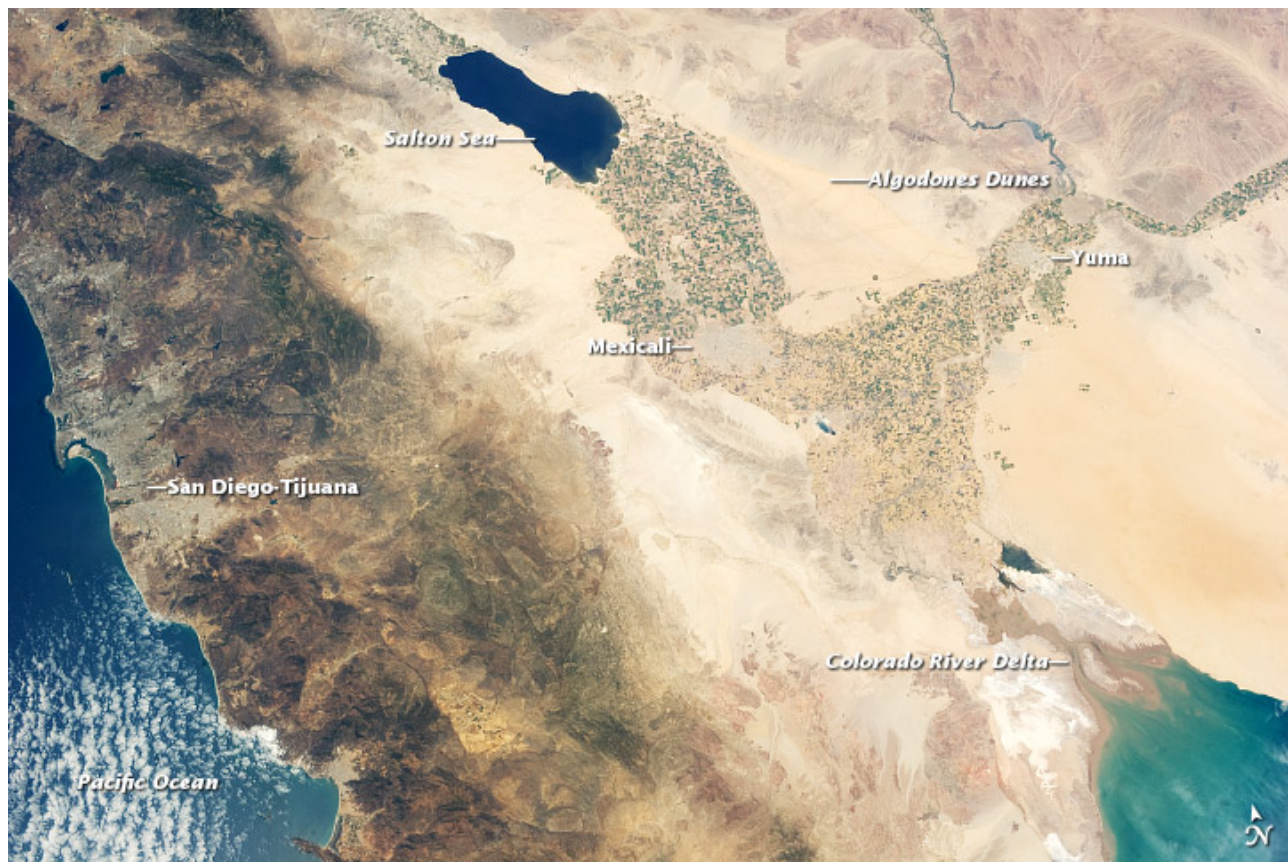

Figure 10. Salton Trough which emerges in the Colorado River valley.

apply them to current land use and water management behaviors and decisions which would need to include aggressive conservation and efficiency measures.

\subsection{Geology and Soils}

During the Cretaceous period, about 100 million years ago, much of western North America was still part of the Pacific Ocean. Between 50 and 75 million years ago [4] the collision of the Farallon Plate with the North American Plate created Tectonic forces which pushed up the Rocky Mountains. The mountain building event was known as Laramide orogeny. The Colorado River was formed as a west-flowing stream draining the southwest portion of the range. The uplift also diverted a tributary of the Mississippi River, the Green River, and west towards the Colorado River.

The sequence and time scale of the river's present course and Grand Canyon is uncertain (Figure 2) and (Figure 4). The Gulf of California was formed by faulting processes along the boundary of North America and Pacific plates around 12 to 5 million years ago. The Colorado flowed west to an outlet, possibility Monterey Bay, on the Pacific Ocean where the river most likely played a role in creation of the Monterey submarine canyon [5].

The Colorado River brought its load of silt from the mountains and hills of the watershed above the Gulf of California. Eventually it created a natural sediment dam which separated the Salton Sea, approximately $71 \mathrm{~m}$ below sea level, to the north from the Gulf of California. The Colorado then cut a channel into the lower Gulf. The upper waters, cut off from the Gulf, gradually evaporated, forming extensive desert creating a petrified forest (Figure 11) and (Figure 12) to the north and near the Grand Canyon. 


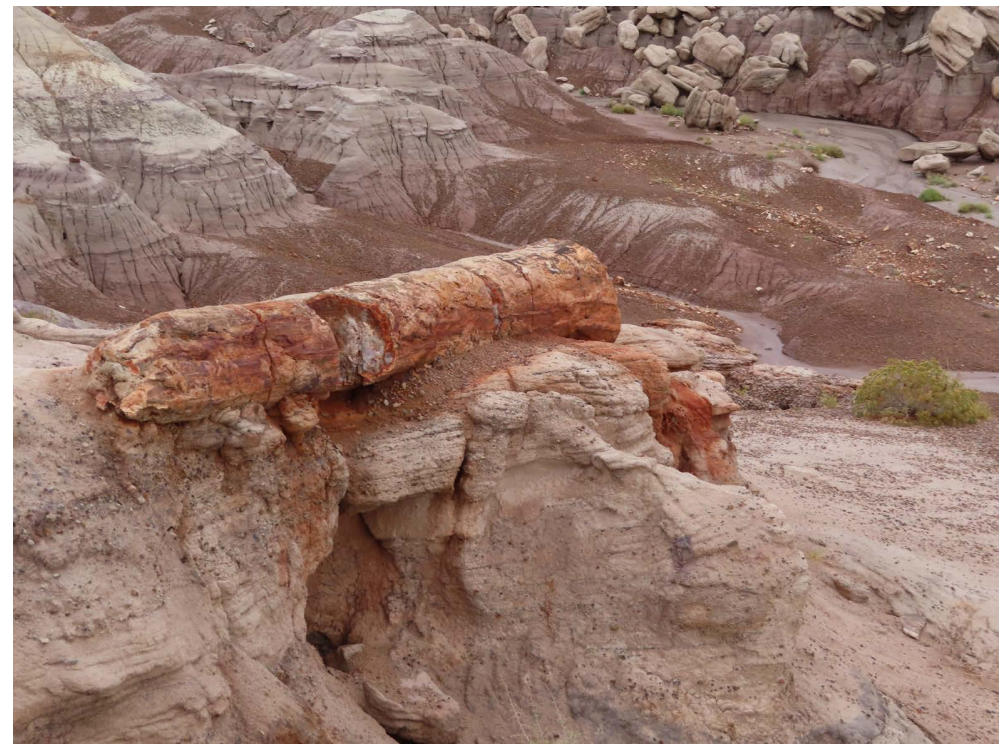

Figure 11. A petrified log in the Petrified Forest.

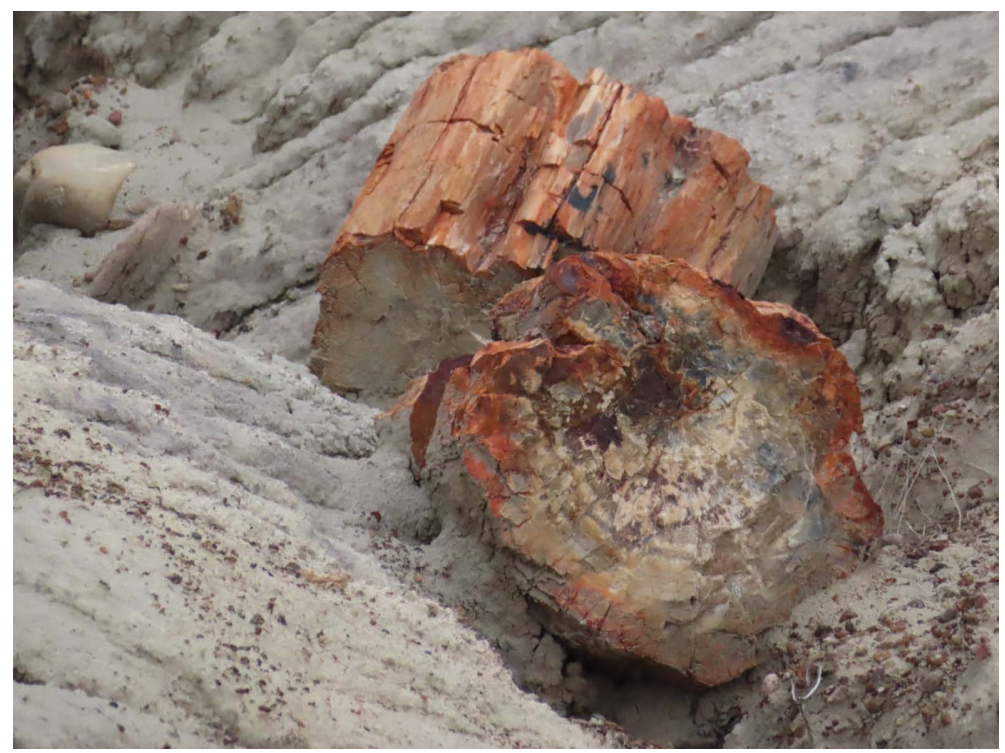

Figure 12. A cut petrified log.

\subsection{Climate}

The average summer temperature in the Lower Colorado River valley is 87 degrees $\mathrm{F}$. In the winter, the average temperature is 55 degrees. The seasonal rainfall in the valley is $5 \mathrm{~cm}$ with $2.5 \mathrm{~cm}$ received during the growing season (April to September). The relative humidity is $20 \%$. Without irrigation water from the Colorado and Gila rivers, crops cannot be grown in the Lower Colorado River valley.

\subsection{Plant and Animal Life}

The upper elevations of the headwaters of the Colorado River have Alpine tundra and coniferous forests (Figure 13) and (Figure 14). The semiarid plateaus 


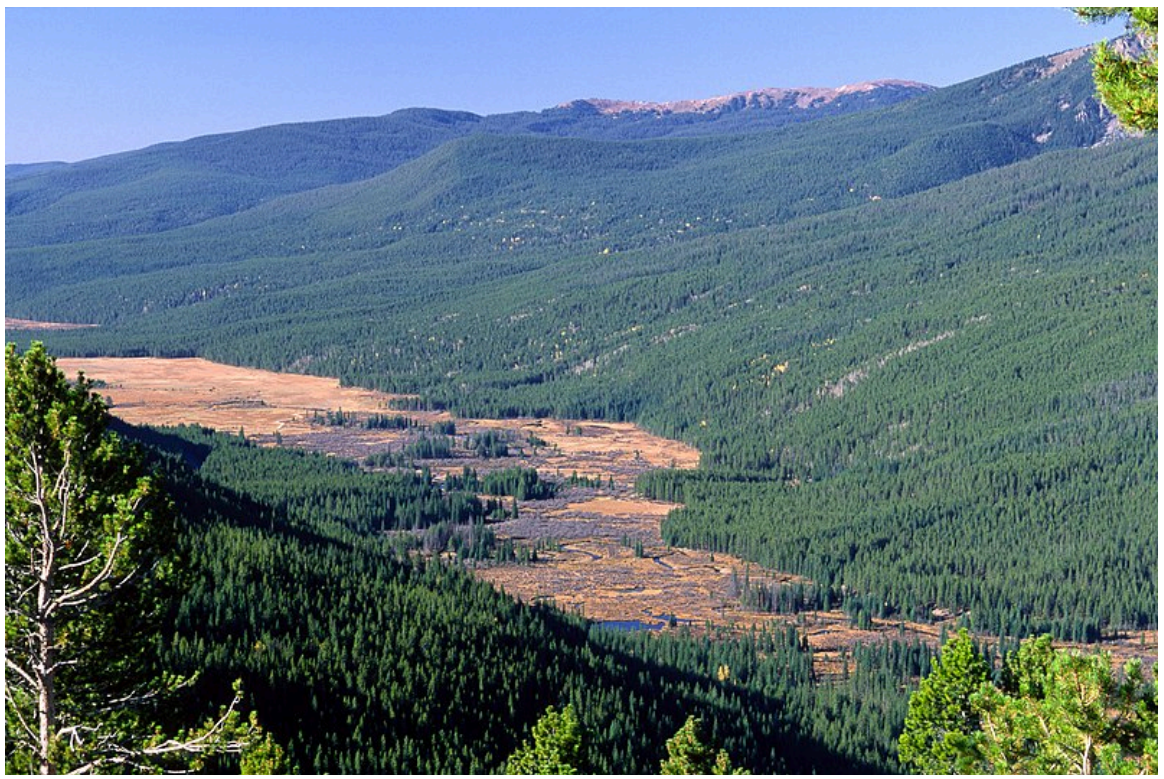

Figure 13. Colorado headwaters-Kawuneecho River.

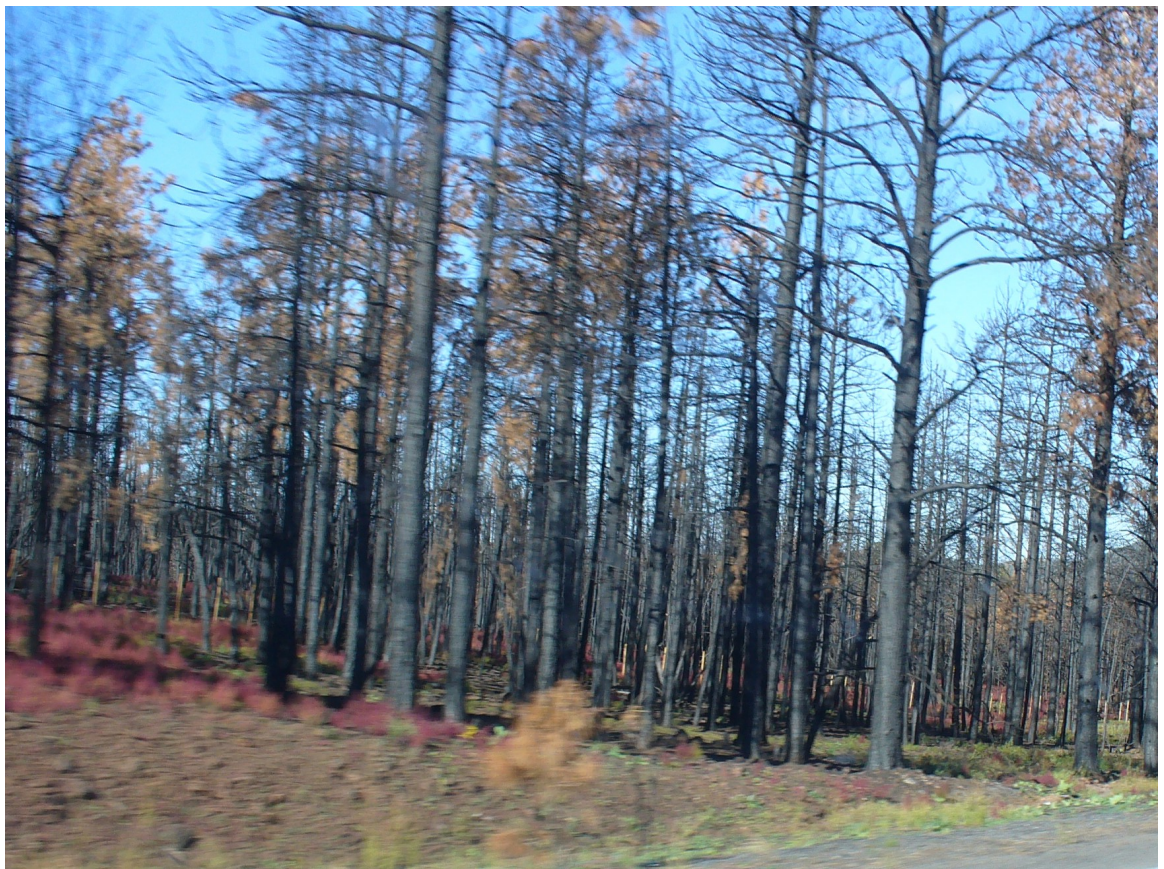

Figure 14. A burnt pine forest.

and canyon support pinon pine (Pinus edulis), juniper (Juniperus communis), sagebrush (Artermisia tridetata) and creosote bush (Larrea tridentate) and other desert mammals including elk (Cervus canadensis), bobcat (Lynx rufus), mountain lion (Puma concolor) and coyote (Canis latrans). Beavers (Castor canadensis), muskrat (Ondatra zifethicus) and birds including bald eagle (Haliaeetus leucocephalus) and Condor (Gymnogyps californianus) (Figure 15) occupy the middle and upper elevations. Streams are lined with willow (Salix babylonica), cottonwood (Populus deltoids) and tamarisk (Tamarix ramosissima). Accidentally 


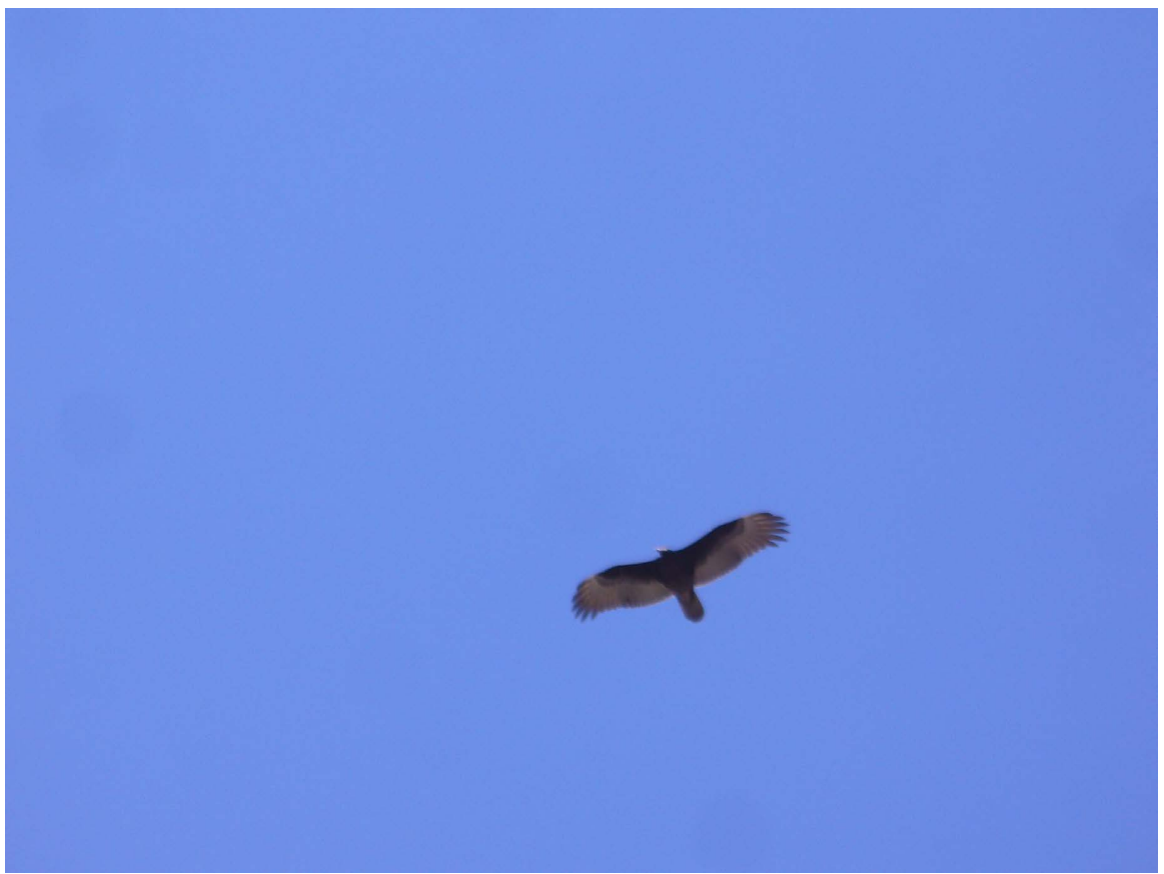

Figure 15. A California condor.

introduced in 1850s, the tamarisk shrub has spread along the river. It has deep roots and high transpiration rate through its leaves consuming large amounts of water. To support the ranching economy large predators were eliminated. River otters are gone as are 4 native fish (humpback chub (Gila cypha)), bonytail chub (Gila elegans), razorback suckers (Xyrauchen texanus) and Colorado squaw fish (Ptychocheilus lucius).

\subsection{Artifacts by Prehistoric People}

The southwestern United States has an extensive and rich history and prehistory for Native Americans who made some of the finest stone tools, ceramics, hand-made decorative items, hand-woven rugs and beautiful beadwork goods found nowhere else in the world. Prehistoric pottery, especially Anasazi and Hohokam, have been recovered by archaeologists and land owners. Pottery occurs in completely undamaged condition because of predominantly dry desert conditions for thousands of years [6]. Moisture along with freezing and thawing can degrade and destroy ceramic vessels resulting in fewer surviving examples. Chipped stone implements were made from chalcedony, agate, colorful jasper, chert, multi-colored basalt, obsidian and petrified wood (Figure 11 and Figure 12) the Paleo Indian, Archaic and Desert Traditions including Developmental, Classic, Historic and Transitional periods.

The earliest archaeological record for the southwestern United States began around 13,200 years ago. Many Paleo Indian implements were first described in the southwest which included the Clovis from a mammoth kill site near Clovis, New Mexico at Blackwater Draw in 1937. The Folsom spear point found at Wild Horse Arroyo near Folsom, New Mexico, at a bison kill site, was discovered in 
1927. The Agate Basin point was found in association with a bison kill site in Wyoming. The Midland point was first described at a site near Midland, Texas. Paleo hunting points were attached to short spears that sat in a larger and heavier thrust spear [6]. The shorter shafts with the attached point served as detachable and reloadable implements for large dangerous prehistoric and now extinct game.

The Archaic period, 8000 to 2300 years ago, was characterized by triangular points with the use of the atlatl spear thrower for present day game. The Desert Tradition sequence in the southwestern U.S. commenced nearly 2300 years ago. The majority of the chipped stone artifacts, made by percussion and pressure flaking, found by archaeologists and land owners, were arrow points used with the invention of the bow and arrow about 1600 years ago. Large triangular points were re-sharpened along the length of the sides and were actually knives [7]. Artifacts that were re-sharpened exclusively at the tip were hunting points. Most artifacts found today had been exhaustively re-sharpened and were thrown away by their prehistoric users [8].

\subsection{Transitional and Historic Native Americans}

The prehistoric people of the Anasazi lived on individual scattered farms in the western Colorado River plateau of northern Arizona and New Mexico. Their crops of corn and squash prospered and their culture spread from A.D. 1000 with consistent rainfall [9]. However, according to tree ring growth at Sand Canyon, from A.D. 1125 to 1180 and 1270 to 1274 along with a following 24 -year drought in the later $13^{\text {th }}$ century, the prolonged drought created food scarcity and triggered conflict. The Anasazi were forced to build fortress-like cliff-side dwellings at Mesa Verde and Chaco Canyon. After being attacked and their grain stores burned or looted, the Anasazi migrated to the Rio Grande and Colorado River valleys where irrigation was still possible.

The Southern Paiute and Ute Indian nations (200 A.D.) gathered and hunted in canyon lands of the upper Colorado basin for hundreds of years (Figure 16). The Hohokam Indians [6] created the largest prehistoric canal irrigation system in American West on the Gila and Salt rivers near the current city of Phoenix, Arizona. Several hundred kilometers of canals were constructed and are still visible from the air or on aerial photographs. The Hohokam grew maize (Zea mays), jack beans (Canavali ensiformis), kidney bean (Phaseolus vulgaris), tepary (Phaseolus acutifolius), lima beans (Phaseolus lunatus), amaranth (Amaranthus graecizans), squash (Cucurbita pepo), gourds (Cucurbitaceae lagenaria), tobacco (Nicotiana tabacum) and cotton (Gossypium hirsutum) [6]. Over time, soil management difficulties increased. Irrigated soils became waterlogged as a result of inadequate drainage. Sediment filled the Hohokam canals and salts accumulated in the fields reducing the soil productivity and crop yields. The adobe walls of the villages were unstable as a result of salt erosion. Salt weathering of the adobe walls resulted in their crumbling and eventual collapse [6]. By 1400 A.D., 


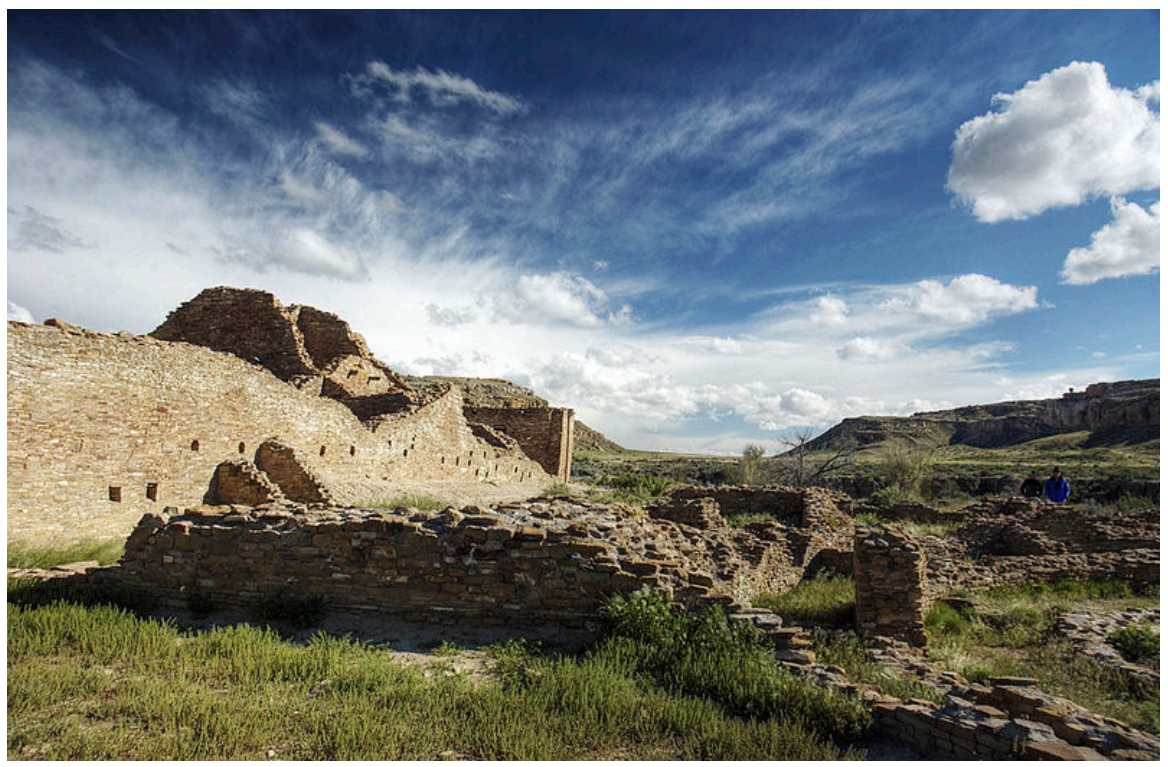

Figure 16. Cliff Dwellings Ordaz Chaco Canyon.

the irrigated fields were largely abandoned. Many of the modern canals paralleled or overlapped the ancient Hohokam canals. Soil erosion and salinity problems remained a threat to the stability of the modern irrigation systems. Modern technology has enabled better crop production through improved water management and more effective soil drainage systems to remove salt from the soil profiles. The Yuma tribes farmed the floodplain of the Colorado River and hunted. The river was too large with an irregular flow for canal irrigation. The economic exploitation of the region by the Europeans made it difficult for Indian groups to maintain their traditional way of life on the river.

\subsection{Global Temperatures in the Southwestern United States}

The year A.D. 1400 dovetails with the Little Ice Age-Phase One of A.D. 1300 to 1550. As with 1500 year natural warming cycles, the last being the Medieval Warming period, from A.D. 900 to 1300, brought on by cyclical normal-occurring solar flare increases (massive solar ejections or M.S.E's), M.S.E.'s dropped worldwide temperatures to minimum levels by A.D. 1400 [9]. This profoundly affected the Hohokam people of the Southwest with excessive cold and serious droughts reducing harvest or subjecting the inhabitants to devastating crop failures.

\section{European and American Settlement}

In 1540 Hernando de Alarcon, an early Spanish explorer, sailed up the Colorado River past the site of the present day city of Yuma (Figure 17) and (Figure 18). At that time, Indians of the Yuma culture were living along the banks of the Colorado and Gila rivers. During the period of the American Revolution, Padre Francisco Garces established two missions in the area. This area was located south of the Gila River and remained in Mexican hands until the completion of the Gadsden Purchase in 1854. In the early days, it was impossible for wagon 


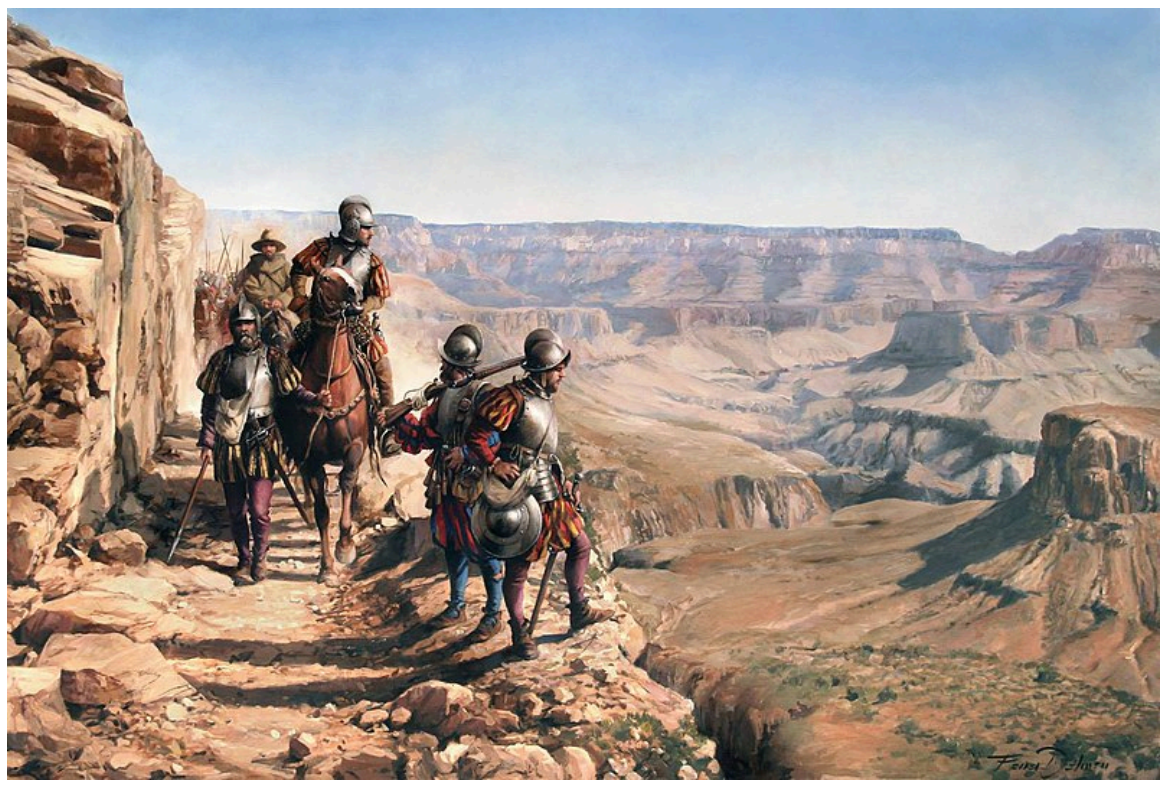

Figure 17. Drawing La Conquista Del Colorado.

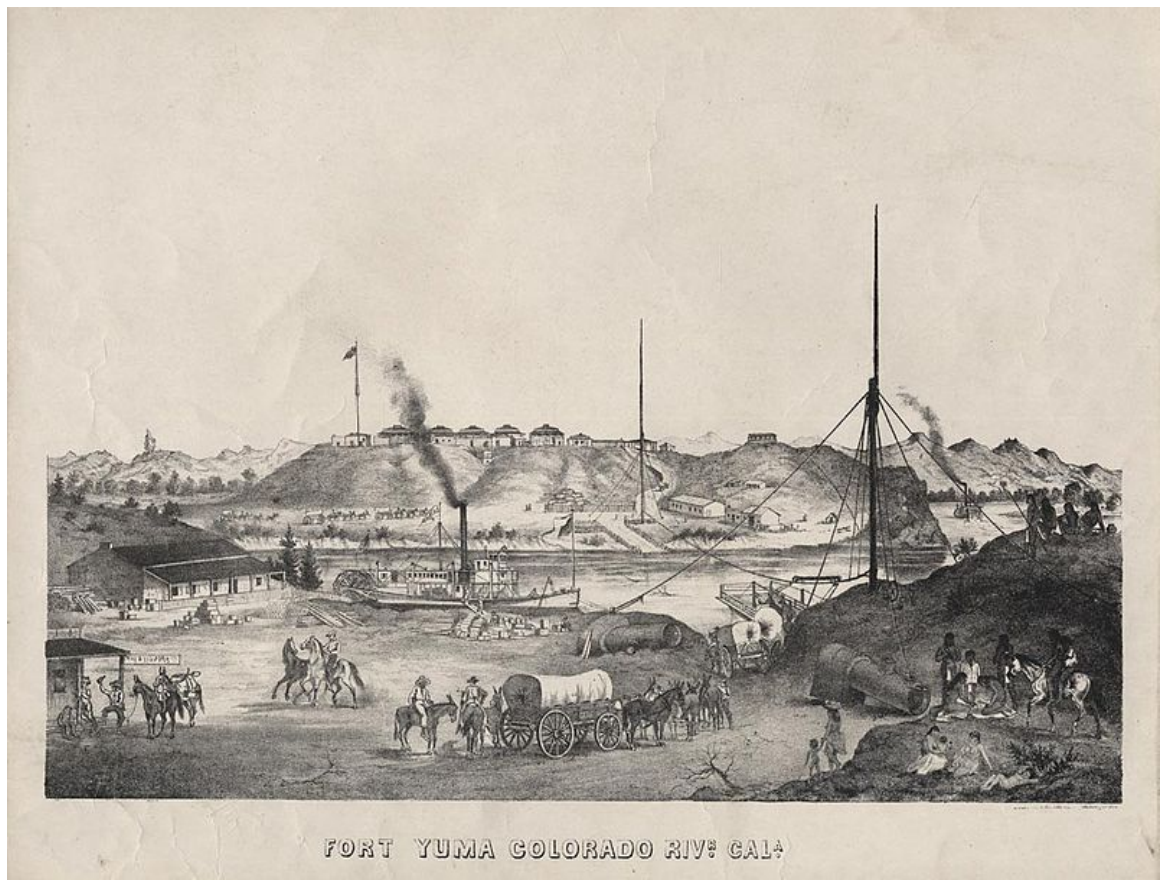

Figure 18. Fort Yuma in California during the Gold Rush and a few boats on the Colorado River.

trains to traverse the rugged terrain north of the Gila River. Many immigrants to California gold fields (Figure 18) followed the Gila Trail, which crossed the Colorado River near where Yuma city is located.

\subsection{Irrigated Soils and Food Crops}

The early farmers in Yuma county area relied on annual spring floods from the Colorado River to provide moisture for crops. When the river dried up, the In- 
dians subsisted on wild plants including mesquite, India tea, and a variety of cacti. In the 1540s European explorers observed Indians carrying on a form of irrigated farming at the confluence of the Gila and Colorado Rivers a few kilometers north of the present day city of Yuma. Father Eusabio Kino, while visiting the Lower Gila Valley in 1700s, wrote of seeing little fields of maize, watermelons, calabasher, and beans.

The first European settlers to practice irrigation on a large scale was Jose Maria Redondo in 1870. The irrigation system included reed and earthen dams and a network of canals approximately $50 \mathrm{~km}$ long to serve 8000 ha of farmland along the Gila River. These structures were washed out during flooding events and had to be periodically rebuilt.

Soils in the Yuma county area, which are typical of the Lower Colorado River watershed can be divided into two groups, valley and mesa soils, and the valley soils have more favorable available water capacities and are more fertile. They are generally silty and clayey, Most of these soils are alkaline with some areas having a salt accumulation. The valley soils are used to produce alfalfa hay, cotton, sugar beets, small grain, grain sorghum, and vegetables. Mesa soils are sandy and have low available water capacity and natural fertility. They are on older terraces of the Gila and Colorado rivers. These soils require special care for successful farming, but crops can be grown. Mesa soils produce citrus fruit, alfalfa, hay, peanuts and small grains.

The Spanish explored and settled the Colorado River basin in 1850s. American surveyors focused on passes, routes, and territorial boundaries. The inland-shipping entrepreneurs assessed the navigability of the river (Figure 18). The federal government funded a major scientific survey in 1870s. The Colorado River was found to have very limited navigation potential. Investigations would focus on river development including irrigation, flood control, hydropower, and water supply [3] after 1900.

In the 1990s the US Department of Interior had been modifying the flow discharge rate of large dams to mimic natural spring floods that modify the channel bed, redistribute sediment and sandbars. The increased flow flushed unwanted river detritus and contaminants. Tensions continue to arise among basin states over interstate water marketing, water allocation, drought management and potential effects of the global climatic change, reservoirs management and Indian water rights.

\subsection{Public Land Distribution in the Western United States}

Since the Revolutionary War land ownership has been an issue. Border disputes and overlapping claims were common [4]. The Land Ordinance of 1785 became the standard land survey method used by the Federal Government to ease the boundary conflicts. A territory was divided into 6-mile squares called "townships" using astronomical starting points. An individual was required to purchase a section 256 ha. By 1800 , the minimum lot was reduced to 128 ha and a 
cost of $\$ 4.10$ per ha remained the price until 1854 .

As a result of changing economy and evolving social climate, public pressure increased to challenge the land policy of the Federal Government. Prior to the American-Mexico War (1846-1848) western settlers pushed for "preemption" which was the right to settle on the land first and pay later. After the war with Mexico, the homestead movement grew. New roadways (Figure 19), railroads (Figure 20), and canals reduced the Western United States farmers need to use

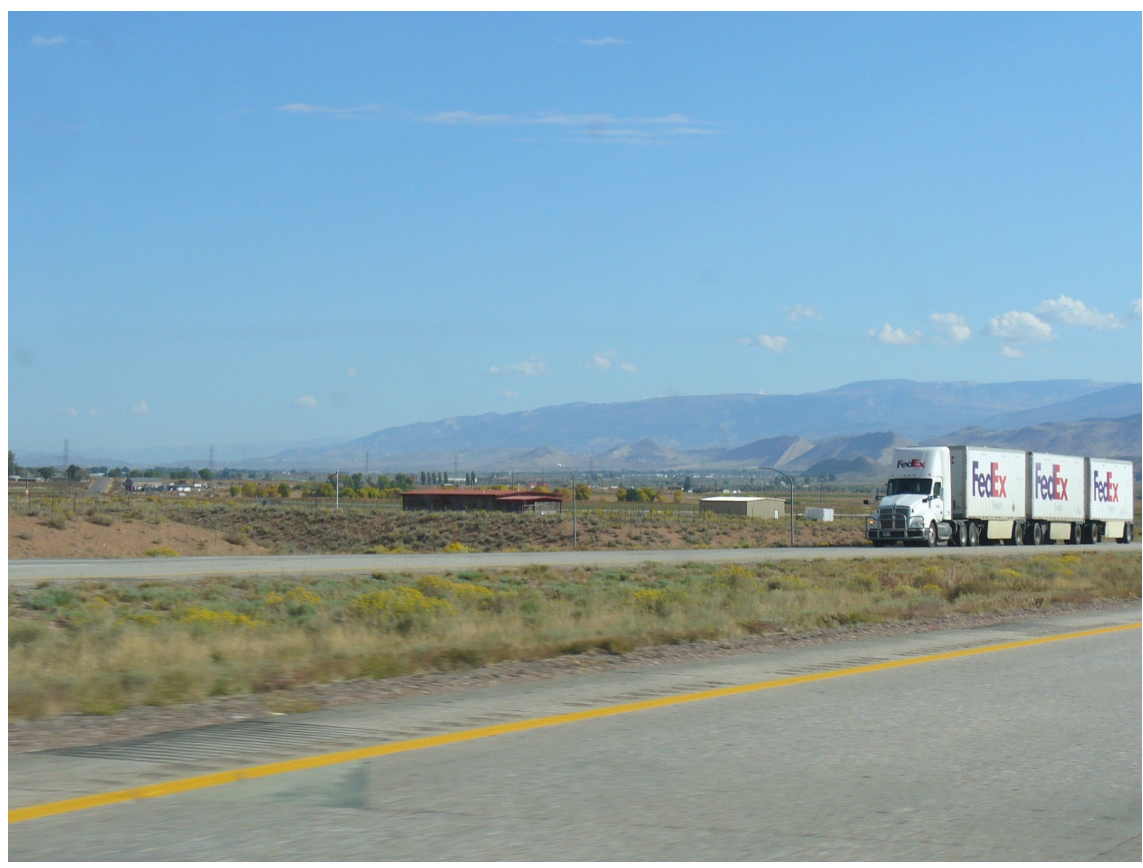

Figure 19. Modern highway crossing the desert in Arizona.

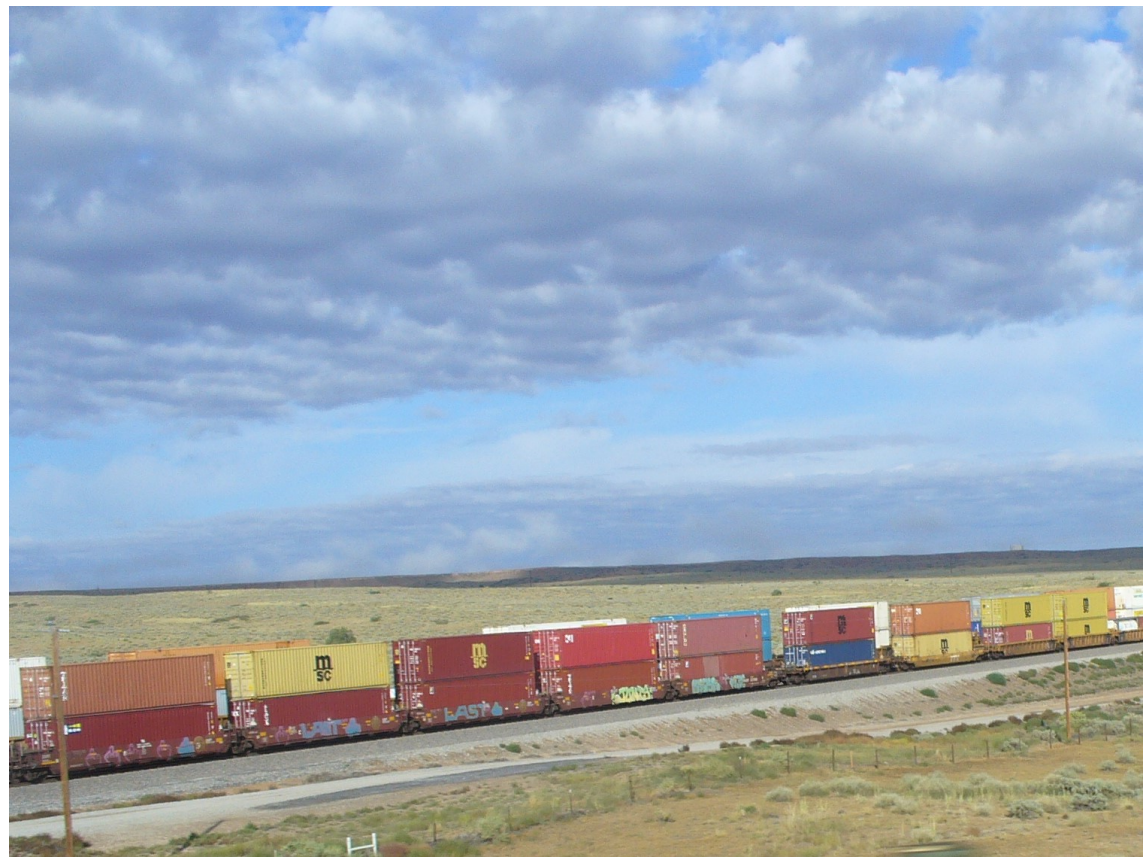

Figure 20. Modern railroad in the Colorado River Valley. 
the Mississippi River Delta harbor at New Orleans [4]. The Homestead Act finally passed on May 20, 1862 and made it possible for any citizen who did not bear arms against the U.S. Government to file a land claim [10]. The Act gave citizens and future citizens up to 256 ha of public land if they lived on it, improved it, and paid a small registration fee.

The Railroad Act was signed in 1862 and by 1869, a transcontinental railroad (Figure 20) stretched across the United States frontier [10]. The western United States land distribution was affected by Federal Government Indian policy. Congress passed the Dewes Act in 1887. Indian reservations were then broken up the Federal Government which gave individual farms to the Indians and the remaining reservation lands was declared open to settlers.

\subsection{General Mining Act of 1872}

In California Gold Rush of 1849 (Figure 18) prospectors and miners found themselves in a legal vacuum. The United States Government had only recently acquired California by Treaty of Guadalupe Hidalgo and laws governing the leasing of mineral lands had little presence in California. Miners in each mining camp organized their own governments. They adopted the Mexican mining laws which had existed in California which gave the discover the right to explore and mine minerals, such as silver and gold, on public lands.

At the end (1865) of the American Civil War eastern congressmen regarded western miners as squatters who were robbing the public patrimony. These congressmen proposed seizure of the western mines to pay a huge Civil War debt. Western representatives successfully argued that western miners and prospectors were performing a valuable service by promoting commerce and settling the land. In 1864, Congress passed a law that deferred to the miners who possessed the ground and instructed the courts deciding questions of contested mining rights to ignore federal ownership.

The General Mining Act of 1872, was approved on May 10, 1872, codified the informational system of acquiring and protecting public land mining claims. The General Mining Act of 1872 was the federal law that authorized and governed prospecting and mining for economically valuable minerals including gold, platinum, and silver, on federal public lands. All 18 years or older citizens of the United States have the right under the 1872 mining law to locate hard rock (lode) or gravel (placer) mining claim on federal lands open to mineral entry. Locatable minerals include lead, silver, platinum, gold, copper, uranium, zinc and tungsten.

According to the Mining Policy Center, mining companies extract $\$ 2$ to $\$ 3$ billion in minerals from public lands every year. From 1872 to 1993, companies produced more than $\$ 230$ billion in minerals from land claims [11].

\subsection{Economic Development}

In 1922, the Colorado River Compact included the seven states that are in drai- 
nage area to facilitate federal investment in reclamation and dams. The total annual flow of the Colorado River was estimated to be $2.1 \mathrm{ha} \cdot \mathrm{m}^{-1}$. A treaty in 1944 allocated $0.2 \mathrm{ha} \cdot \mathrm{m}^{-1} \cdot \mathrm{yr}^{-1}$ to Mexico. Unfortunately, the estimates were based on an abnormally wet period and the available amounts were either non-existent or less than predicted and specified.

In 1928, Congress passed the Boulder Canyon Protection Act. The act authorized the construction of Boulder (now Hoover) dam (Figure 21), a multi-purpose water-storage project. It was completed in 1936. The dam created Lake Mead (Figure 1). The multipurpose dam was for irrigation, hydroelectric power development, recreation, navigation and flood control. In the mid-1960s, the Glen Canyon Dam (Figures 22-24) was completed impounding Lake Powell

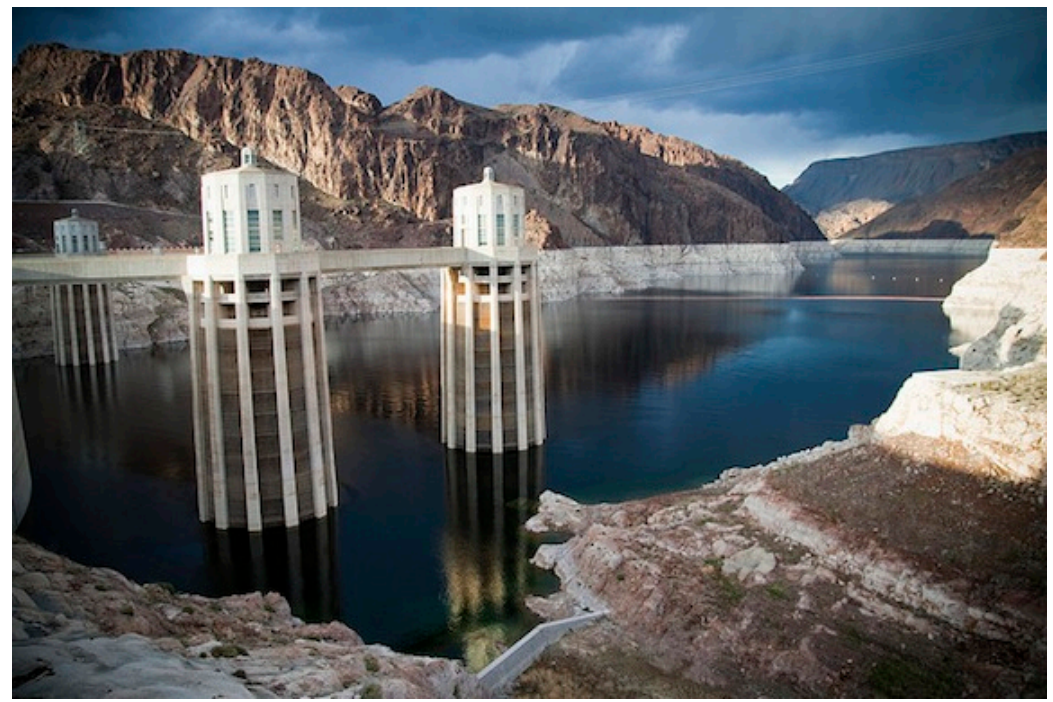

Figure 21. Hoover Dam with rather low water level.

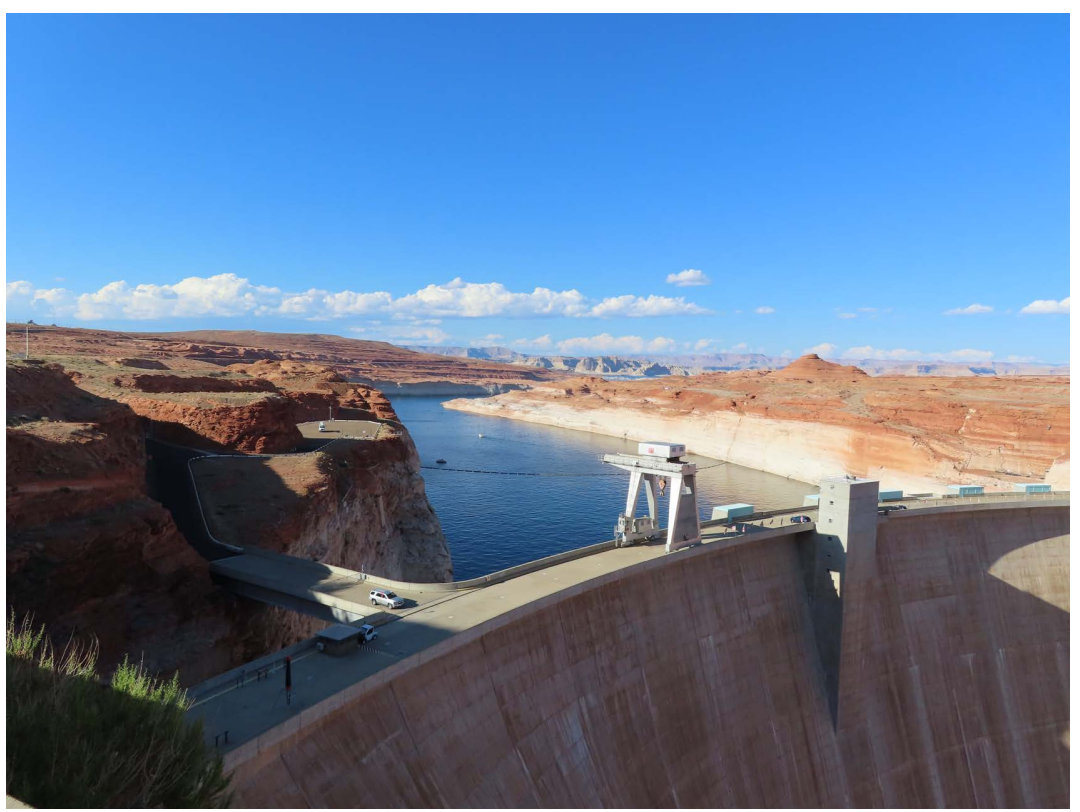

Figure 22. Glen Canyon Dam and Lake Powell. 


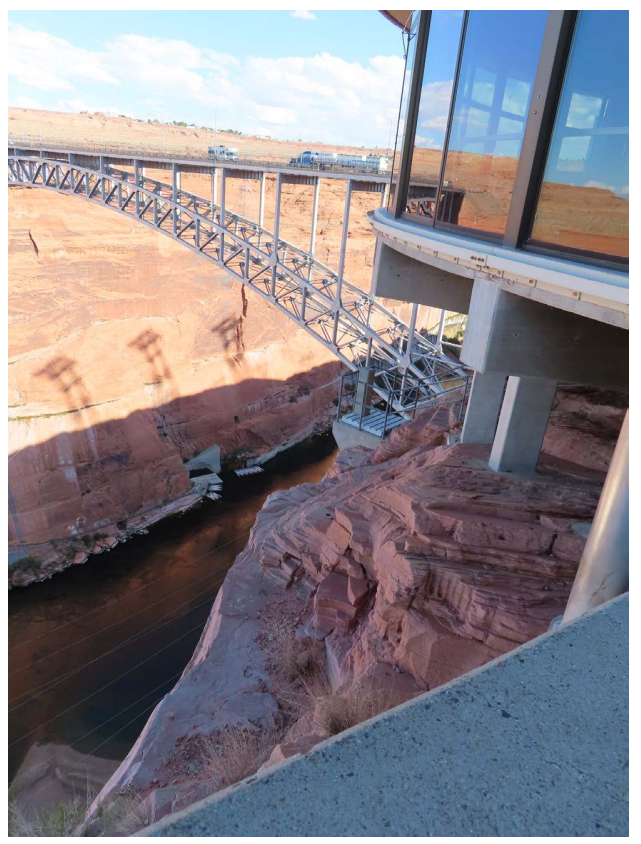

Figure 23. Glen Canyon Dam and Bridge over the Colorado River canyon.

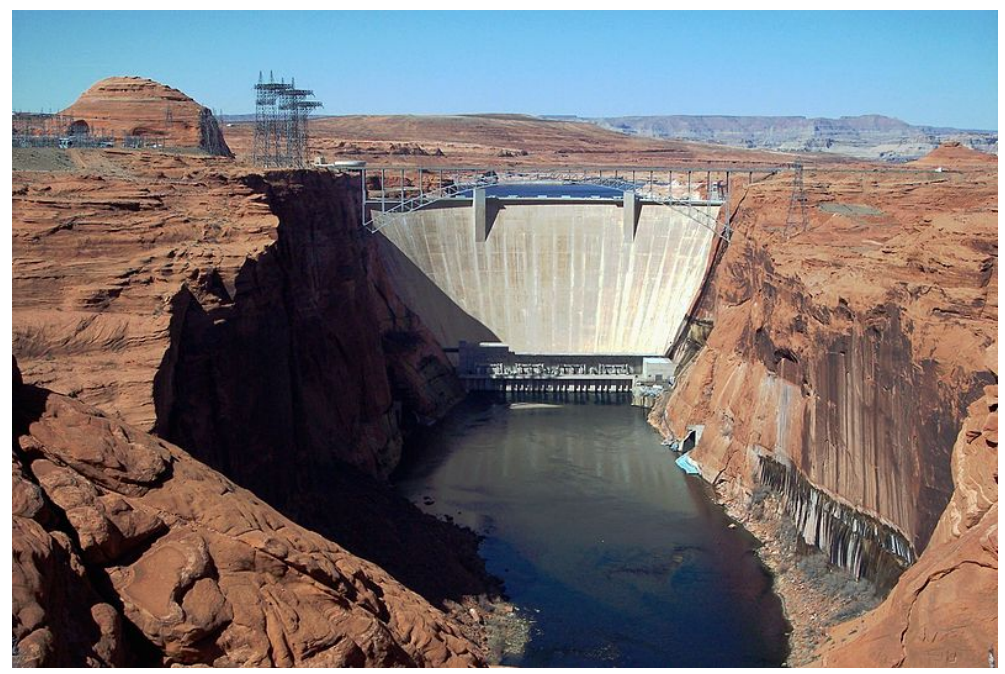

Figure 24. Glen Canyon Dam and the Colorado River canyon.

(Figure 1). There were 3 other dams, the Aspinall (Curecanti) on the Gunnison River, the Navajo on the San Juan River and Flaming Gorge on the Green River, were built and completed on the Colorado River tributaries [12].

\subsection{Water Rights and Fights}

In the Western U.S. the water law principle, Doctrine of Prior Appropriation developed gradually. Prior Appropriation Doctrine is "the rule that among the persons whose property borders on a waterway, the earliest users of the water have the right to take all they can use before anyone else has a right to it" [13]. It is a doctrine that prevails in some American jurisdictions that the person who first diverts and applies the waters of a stream to a beneficial use has a prior right 
to continue use to the extent of his appropriation.

Many streams in the western U.S. had intermittent flows and were not amenable to Riparian Doctrine which was commonly used in the Eastern U.S. The Riparian Doctrine "states that water belongs to the person whose land borders a body of water" [14]. Riparian owners are permitted to make reasonable use of this water provided it does not unreasonably interfere with the reasonable use of this water by others with Riparian rights.

There was a general lack of competition for water resources in the Western U.S. as a result of seasonality of flow and sparse population. Landowners modified river channels to impound water for their own use-first come-first served. The U.S. Government did not anticipate wide spread settlement in the arid West.

In Utah, in the 1800s, the Mormon settlers required some solution to relatively sparse water resources as a result of increased agricultural use. Mormon's established a water allocation system that favored shared use of the water resource and beneficial use (Figure 25). However, beneficial use was replaced by "Prior Appropriation Doctrine".

Prior Appropriation Doctrine grew out of the California gold rush. There was a need due to limited water availability for gold miners to establish some system of water use and mining claims. This was the origin of the "first come, first served" concept of water rights. California which became a state in 1850 adopted the "Doctrine of Prior Appropriation" which allowed the diversion of water from a waterway for use on non-riparian lands. Once a claim is made under the Doctrine of Prior Appropriation it was subjected to "use it or lose it" annual stipulations.

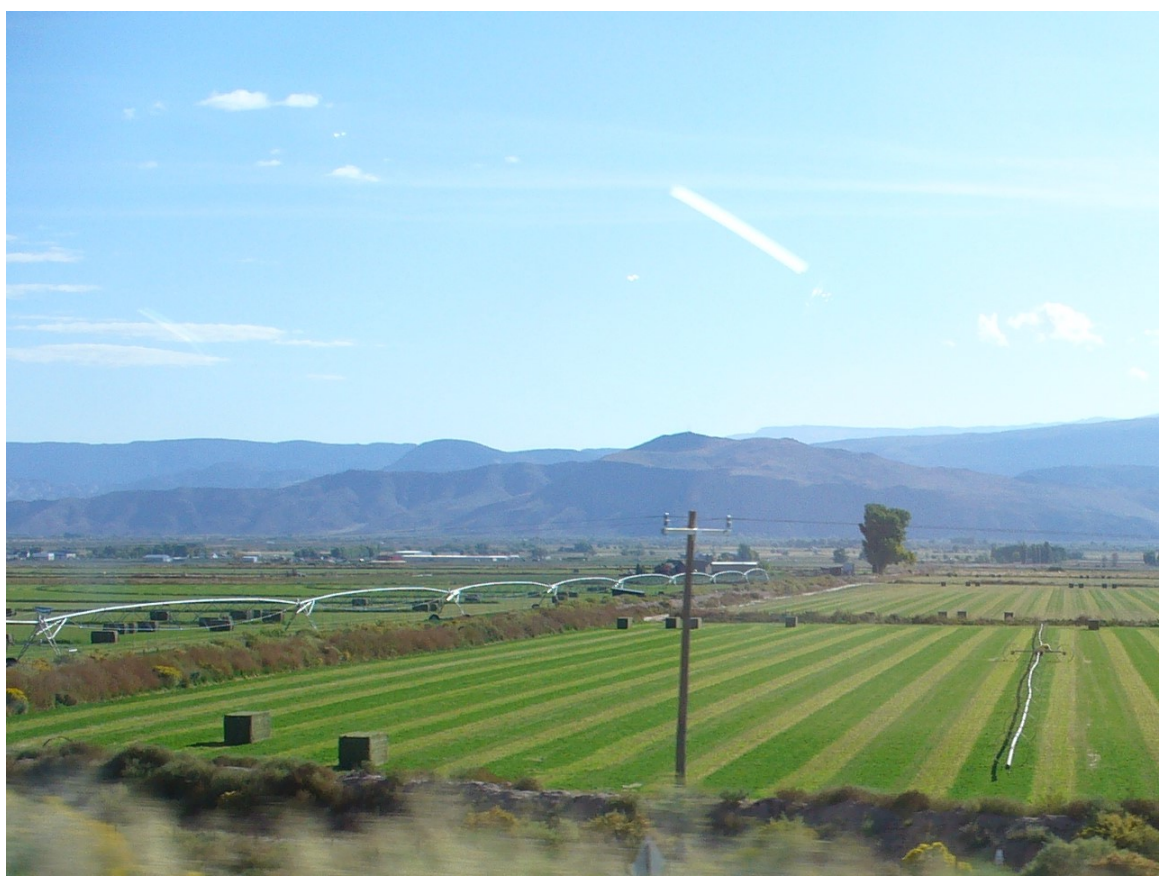

Figure 25. Irrigation equipment and alfalfa bales in Colorado River Valley. 
In 1963, the United States Supreme Court made explicit the amount "reserved" for the Indian nations, apportioned among lower-basin states and for federal public lands. The decision cleared the way for funding the Central Arizona Project which transferred water to Tucson and Phoenix [2]. The project included a mountain tunnel which transferred water from the south end of Lake Havasu that passed through and then was pumped up and into an aqueduct that flows to both cities.

The Colorado River often runs dry (Figures 26-31) before any river water reaches the Gulf of California. Intensive consumption, mostly in United States, has dried up the lower $160 \mathrm{~km}$ of the river and, since the 1960s, the river flow

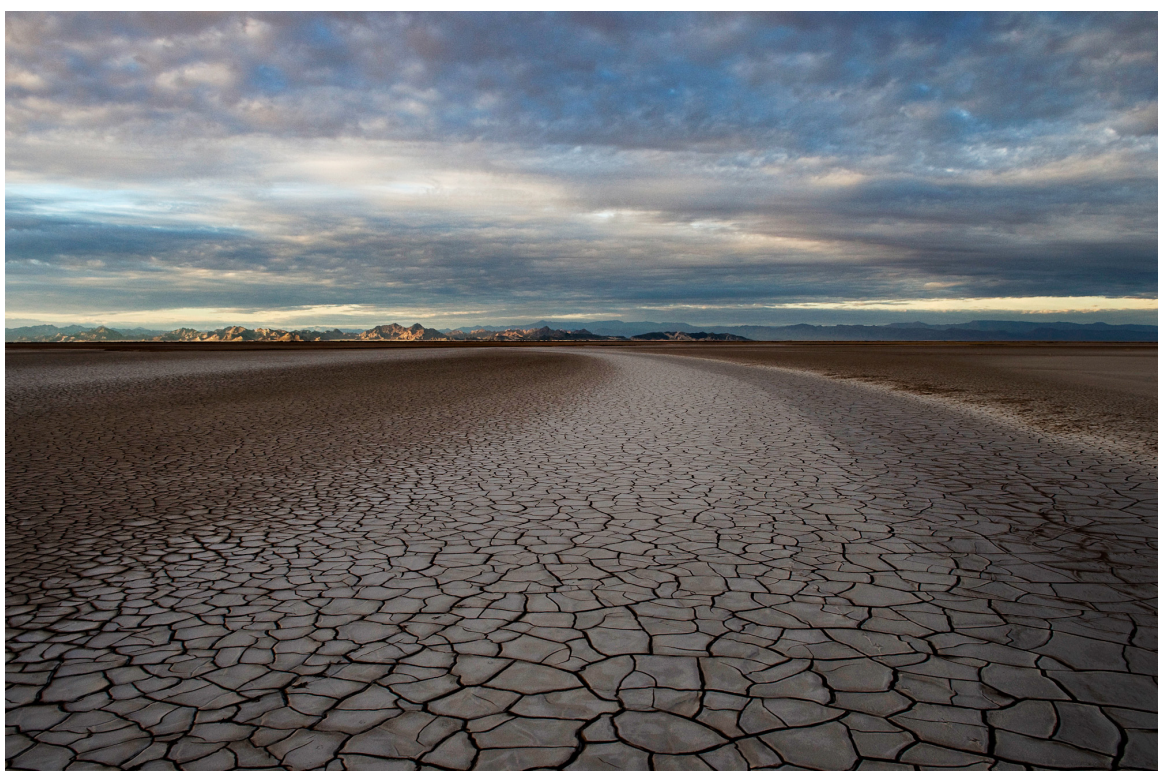

Figure 26. Dry Colorado River sediment.

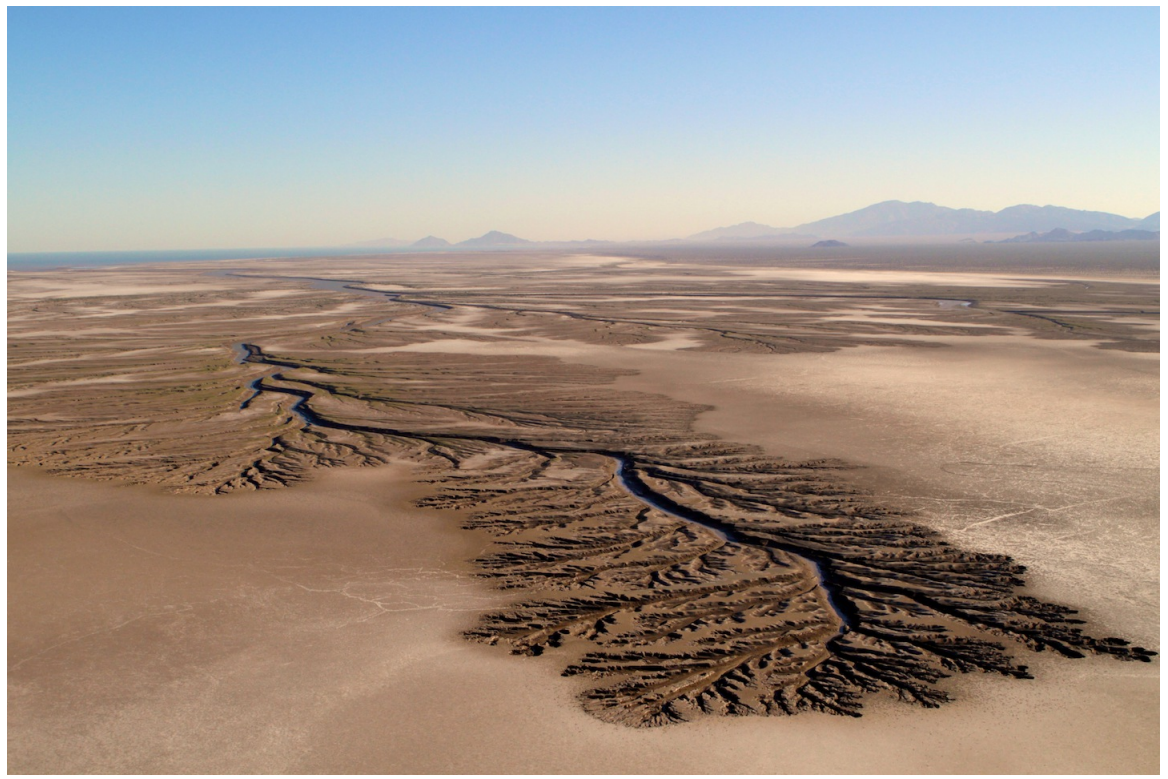

Figure 27. Dendritic drainage pattern in Colorado Delta. 


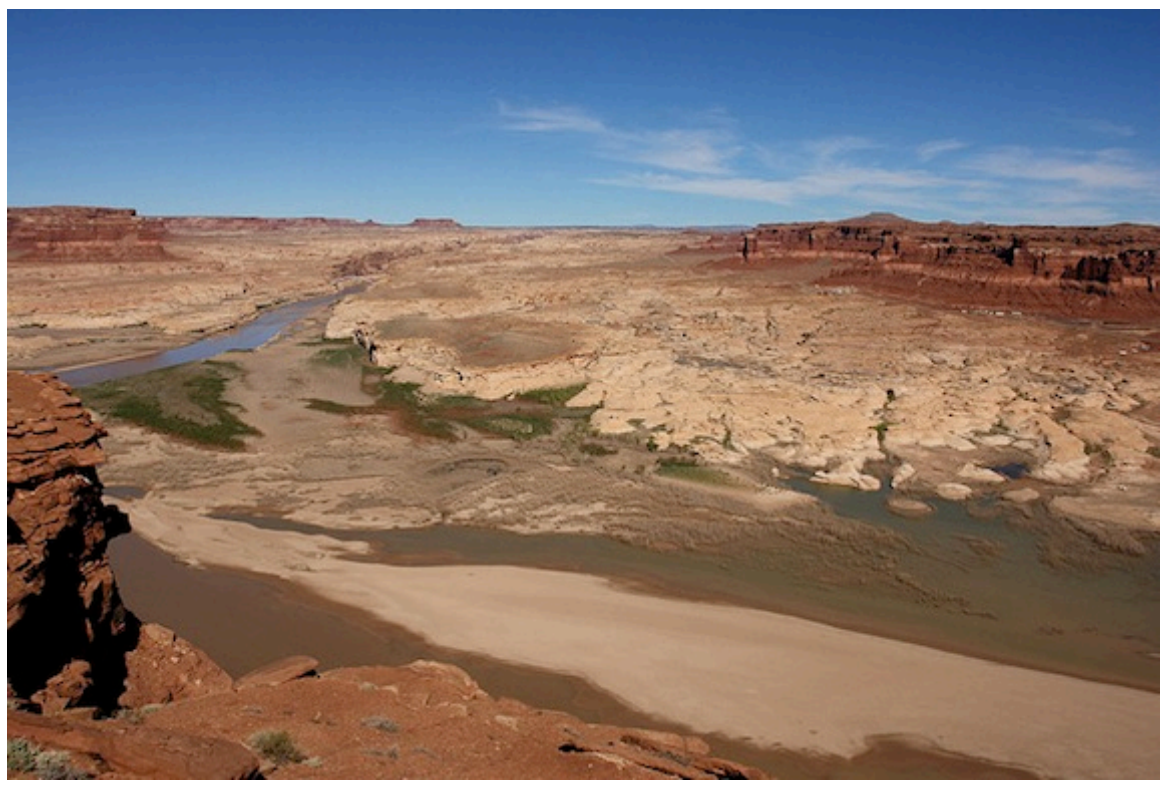

Figure 28. Sandy, dry Colorado tributary river bed.

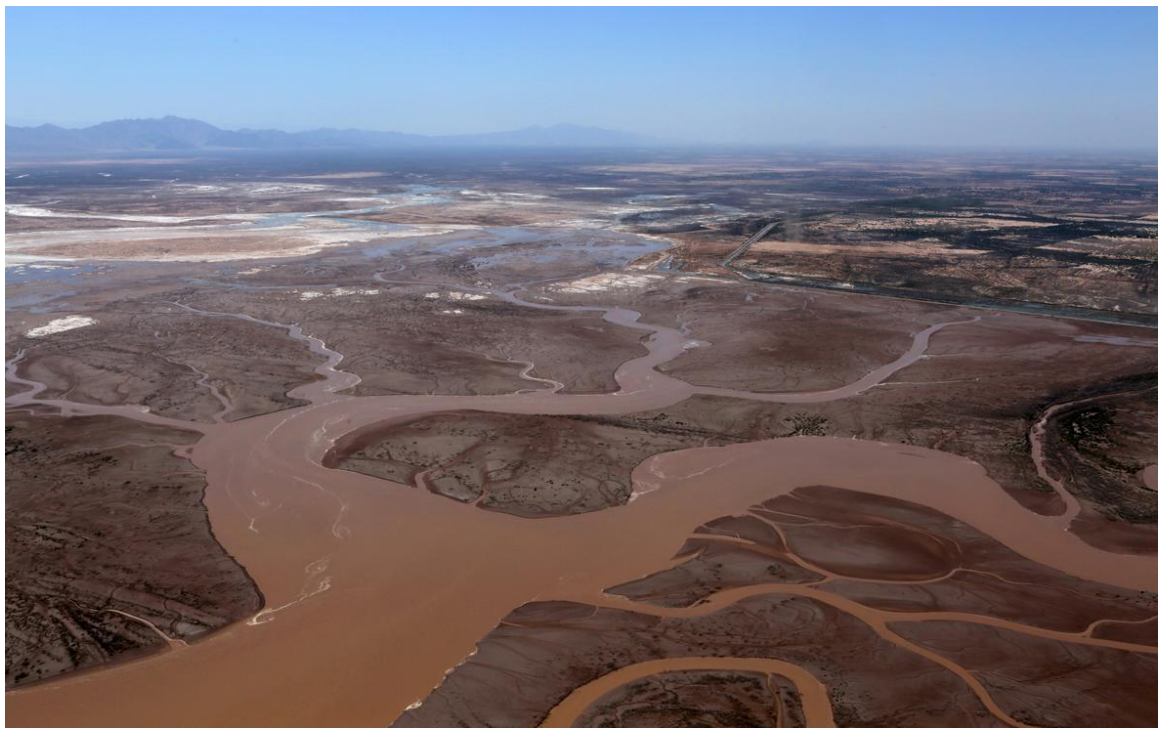

Figure 29. Flowing Colorado River in the Delta near the Gulf of Colorado.

has rarely reached the Gulf of California. The Colorado River Delta is drought prone and its headwater tributaries remain a vital source of water for 40 million people. The states of Arizona and California have attempted to restore the vegetative cover by planting trees and shrubs in the Colorado River valley (Figure 32) and (Figure 33).

\subsection{The Establishment of the U.S.-Mexico Western Border and Immigration Policy}

The modern border took shape following the American-Mexican War. While the Rio Grande formed the dividing line between Mexico and Texas, the border originally moved from El Paso west on a straight line to the Gila River, across 


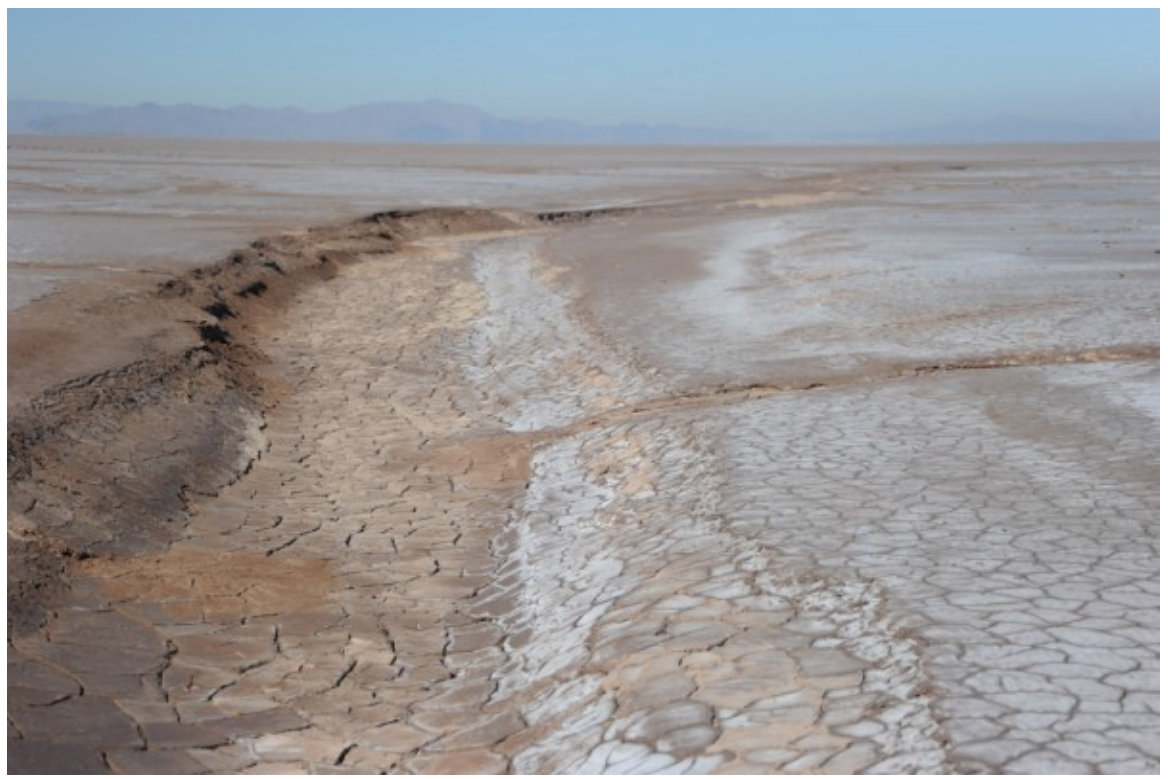

Figure 30. Salt crusted Colorado River sediments in a dry river bed.

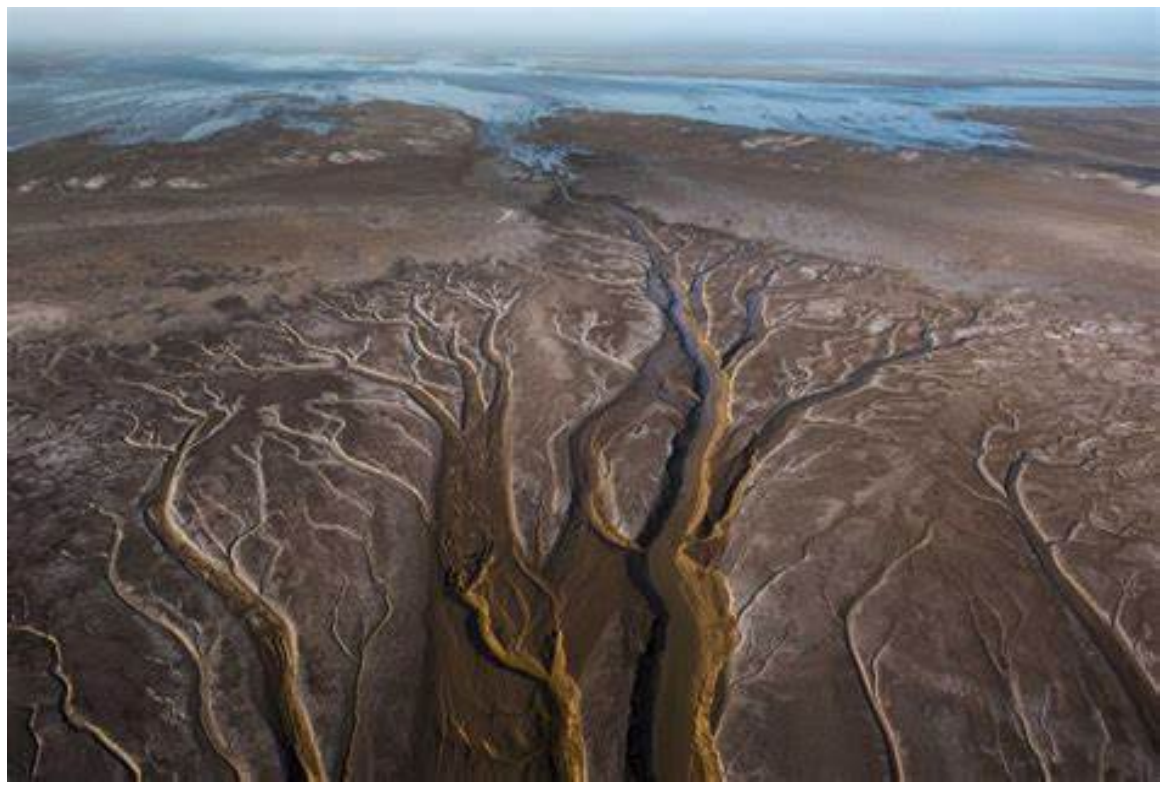

Figure 31. Colorado River Delta drainage pattern during a drought.

the Colorado River and then on another straight line south of San Diego to the Pacific Ocean. Following the Gadsden Purchase of 1854, the borders of New Mexico and Arizona moved further south from the Gila River.

A team of soldiers, surveyors and officials from both countries staked out the border from Tijuana to El Paso. According to St. John [15], an associate professor of history at UC Davis and author of "Line in the Sand: A History of the Western U.S.-Mexico Border". The joint boundary commission underestimated the time and cost it would take to complete the project through such an inhospitable terrain of canyons, mountains and desert. Not until the late 1850s did the boundary commission complete its work. There were no federal limits on 


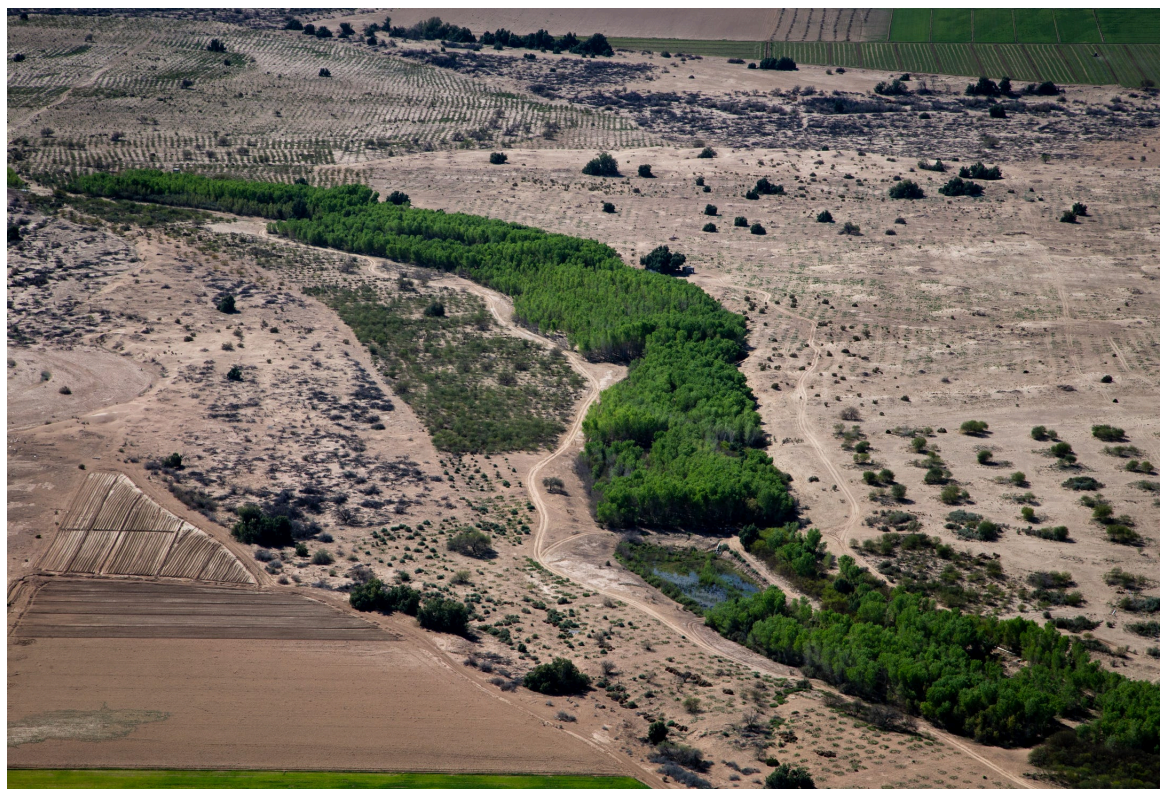

Figure 32. Restoration of plant vegetation in Colorado watershed.

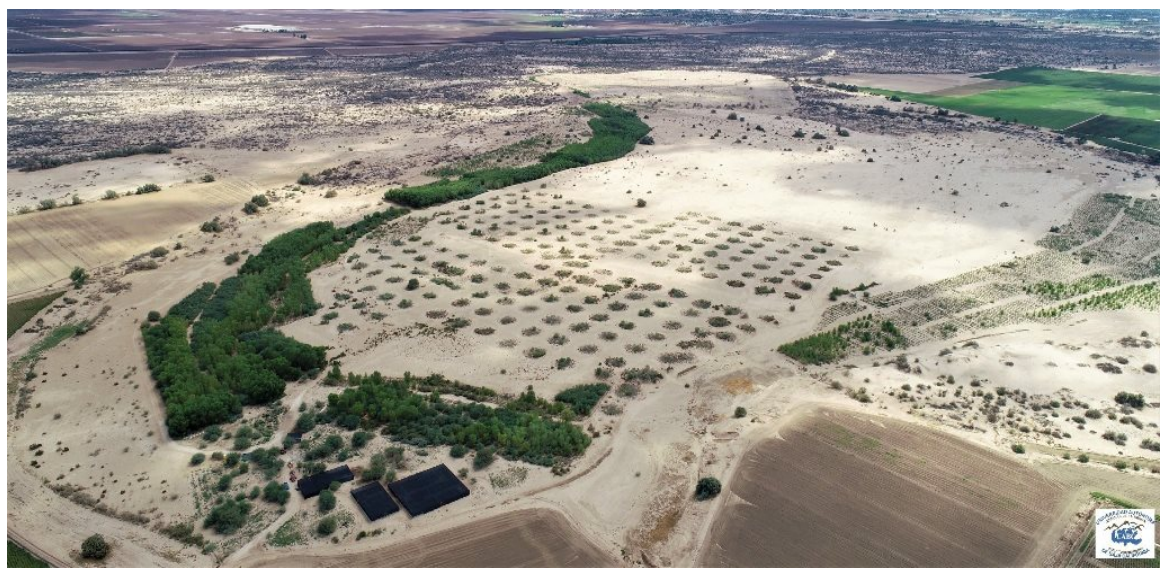

Figure 33. Restoration of vegetation along the Colorado River.

immigration in the decades following the American-Mexican War as citizens from both countries passed freely across the border. After the passage of the Chinese Exclusion Act of 1882, it was Chinese immigrants, not Mexican immigrants that American vigilante groups and authorities first sought to keep from illegally crossing its southern border. "One of the ways that immigrants from China would try to get across the border is to learn a few words of Spanish and disguise themselves as Mexican" [15].

In the 1910s restrictions on the movement of Mexican citizens were not actually enforced by the U.S. government until the decade of the Mexican Revolution when large numbers of refugees came to escape the war and there was a large demand for "Mexican labor" [11]. The United States deployed soldiers to patrol the boundary along with the Texas Rangers and government-sanctioned "home guards" to tightened border security. Following Mexican revolutionary Pancho Villa's deadly raid on Columbus, New Mexico, in 1916 and the subse- 
quent publication of the Zimmerman Telegram proposing a World War I military alliance between Mexico and Germany the U.S. immigration restrictions were enforced.

According to St. John [15], in 1909 the U.S. Bureau of Animal Industry erected the first fence along the frontier to stop the trans-border movement of cattle. During the 1910s border towns erected fences, not as a physical barrier to entry, but to denote the boundary line and channel people into designated crossing points. The United States began the installation of border fences to restrict the movement of unlawful drugs and immigrants in 1993 when President Clinton mandated the construction of a $22-\mathrm{km}$ barrier between Tijuana and San Diego. The Secure Fence Act of 2006 authorized the construction of $1900 \mathrm{~km}$ of vehicle barriers and border fencing which was completed in 2011.

The border between Mexico and the United States is nearly $3200 \mathrm{~km}$ from the Gulf of Mexico to the Pacific Ocean and borders California, New Mexico, Arizona and Texas. Most of the $1900 \mathrm{~km}$ of chain link, barbed wire, post-and-rail and wire mesh fencing has been erected along the $2060 \mathrm{~km}$ west of El Paso [16] [17] but United States plans after 2018 were to expand the fence and wall building effort along the Rio Grande. United States political leadership change in early 2020 had resulted in the wall construction being stopped.

\subsection{Mexico-United States Border Wall}

The 2000-mile border (Figure 34) goes from an arid climate at Tijuana to a tropical climate at Brownsville. Soil tunnels (Figure 35) could be constructed in an arid climate (Entisols and Aridisols) with a low permanent water table [4]. The unconsolidated material and soils (Entisols and Aridisols) are deep and have a low water table. While in the tropical climate with soils (Entisols and Mollisols) to the east have a high water table along the eastern Rio Grande with potential flooding restricted earthen tunnel construction along the eastern half of the border. In the western half of the border area conditions are better for tunnel construction (Figure 36).

Since 1990, over 170 incomplete border tunnels, between Tijuana, Mexico (Pacific Ocean) and El Paso, United States and (Figure 37) have been found. In 2006, the U.S. Border task force found a $730 \mathrm{~m}$ tunnel connecting a San Diego warehouse to Tijuana airport. It was up to $27 \mathrm{~m}$ deep and $1.5 \mathrm{~m}$ high. The walls and floor were cement and clay with lighting and ventilation systems. A drainage system removed the seeping groundwater. Additional significant tunnels were found in 2010, 2012 and 2014 [4].

One of the longest drugs-smuggling cross-border tunnels [4] between the US and Mexico was discovered in 2016 by authorities in San Diego. The $800 \mathrm{~m}$ long soil tunnel was used to transport an "unprecedented cache" of marijuana and cocaine (Figure 37 ). It was the $13^{\text {th }}$ sophisticated secret tunnel found along California's border with Mexico since 2006. In the latest incident, about $6350 \mathrm{~kg}$ of marijuana and $1016 \mathrm{~kg}$ of cocaine suspected of being transported through the 


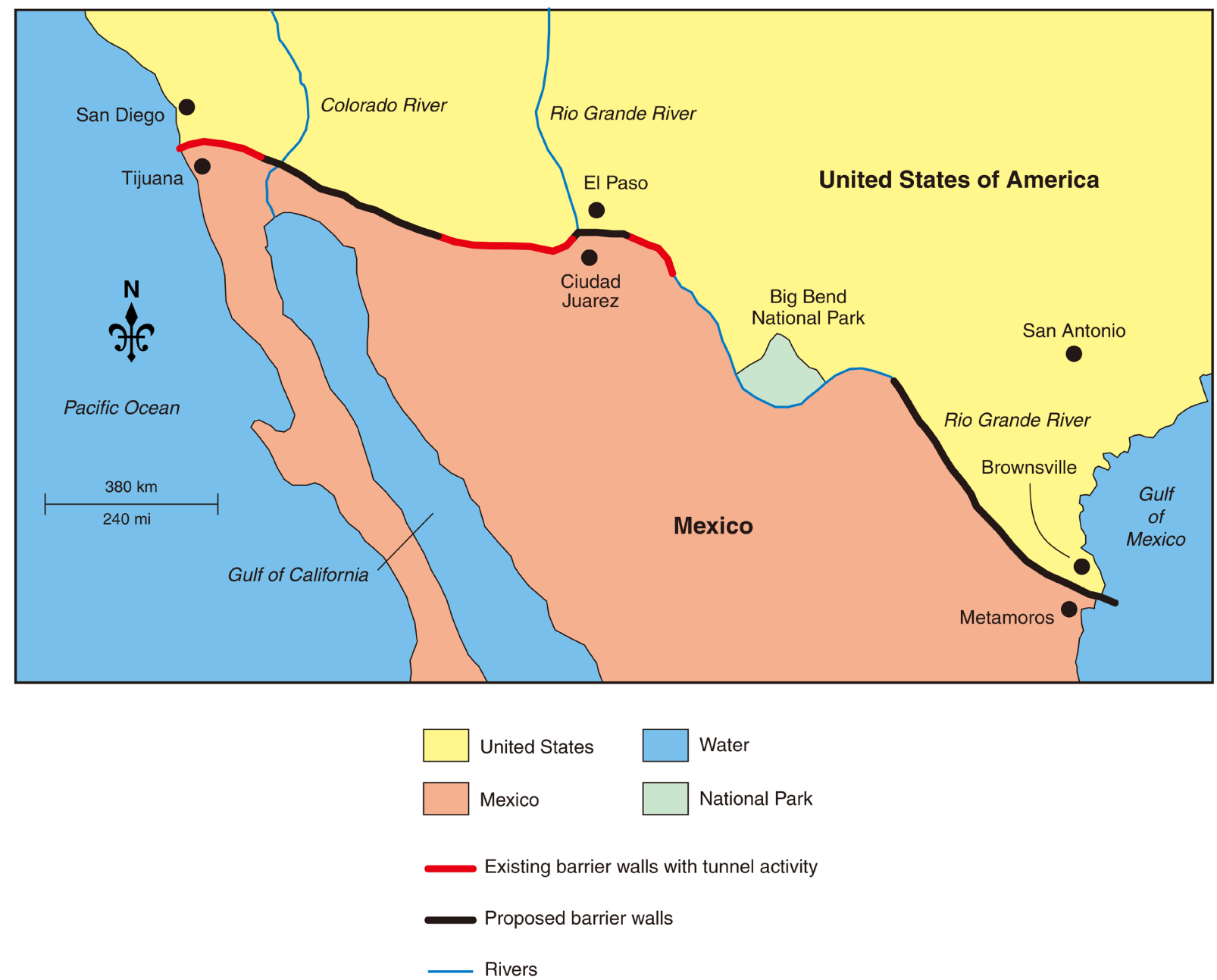

Figure 34. Map of the locations of the existing and proposed barrier walls between Mexico and the United States. Once built, the barrier walls are often undermined by tunnels originating in Mexico. Map by Mic Greenberg.

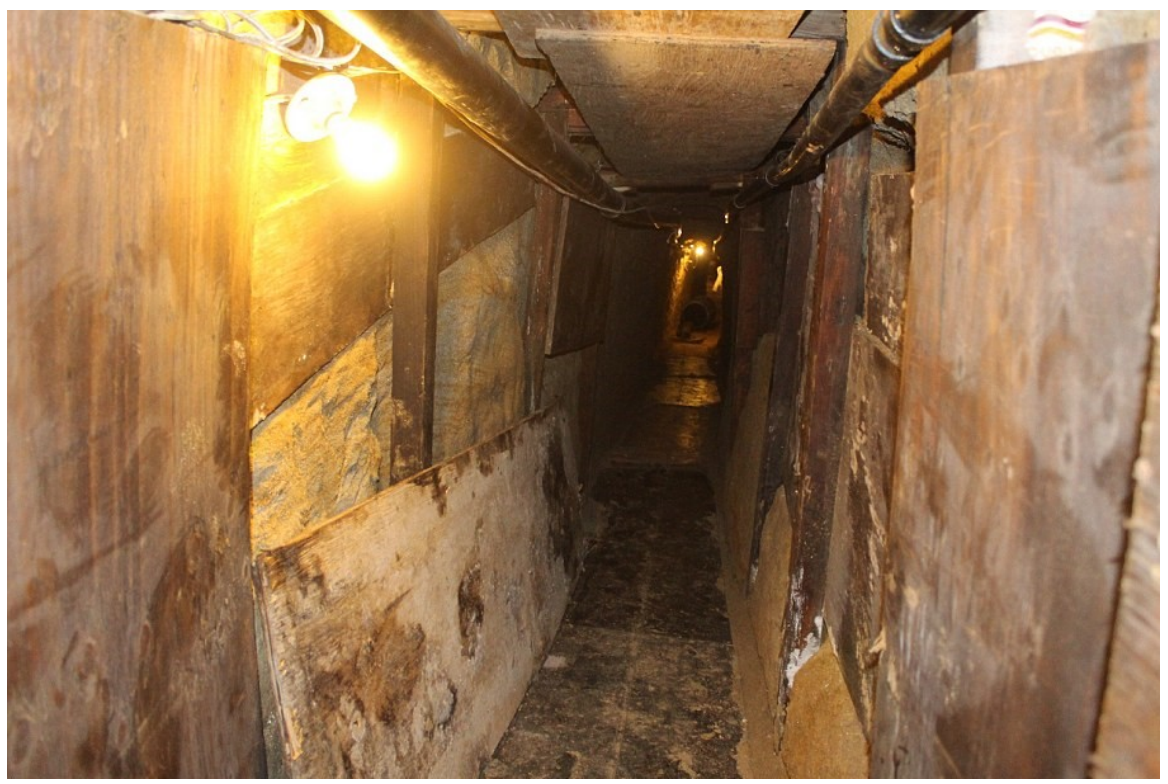

Figure 35. Soil tunnels lined with plywood under the Mexico-United States border. 


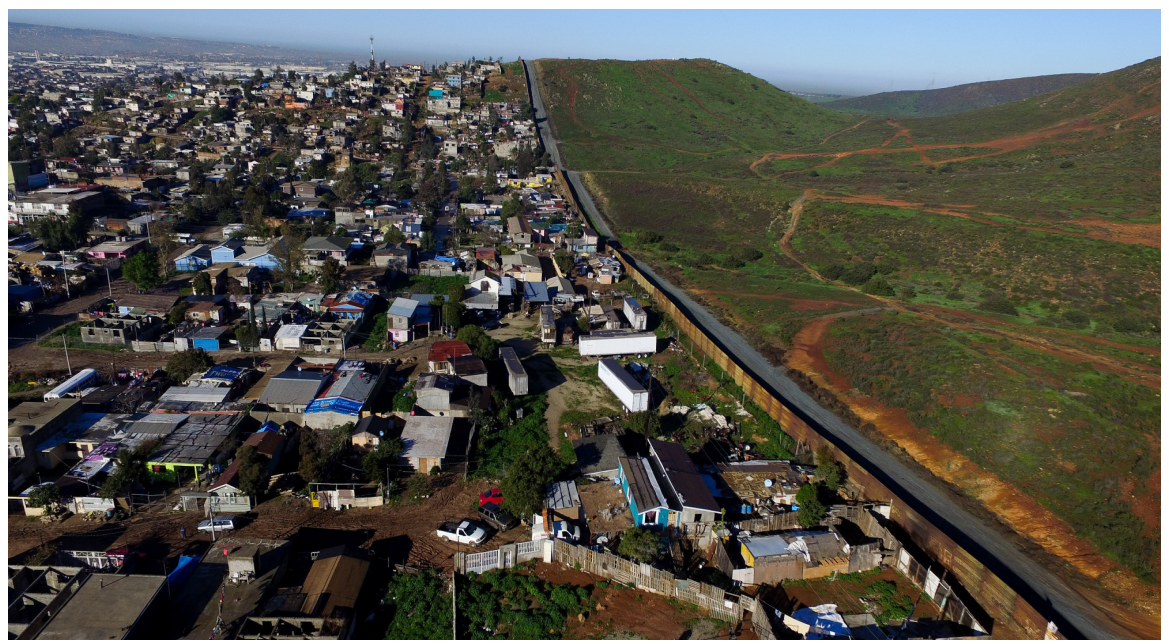

Figure 36. The Mexico-United States rolling landscape. The border wall separates the two countries and the paved road along the border wall is on the United States side and the housing in on the Mexico side.

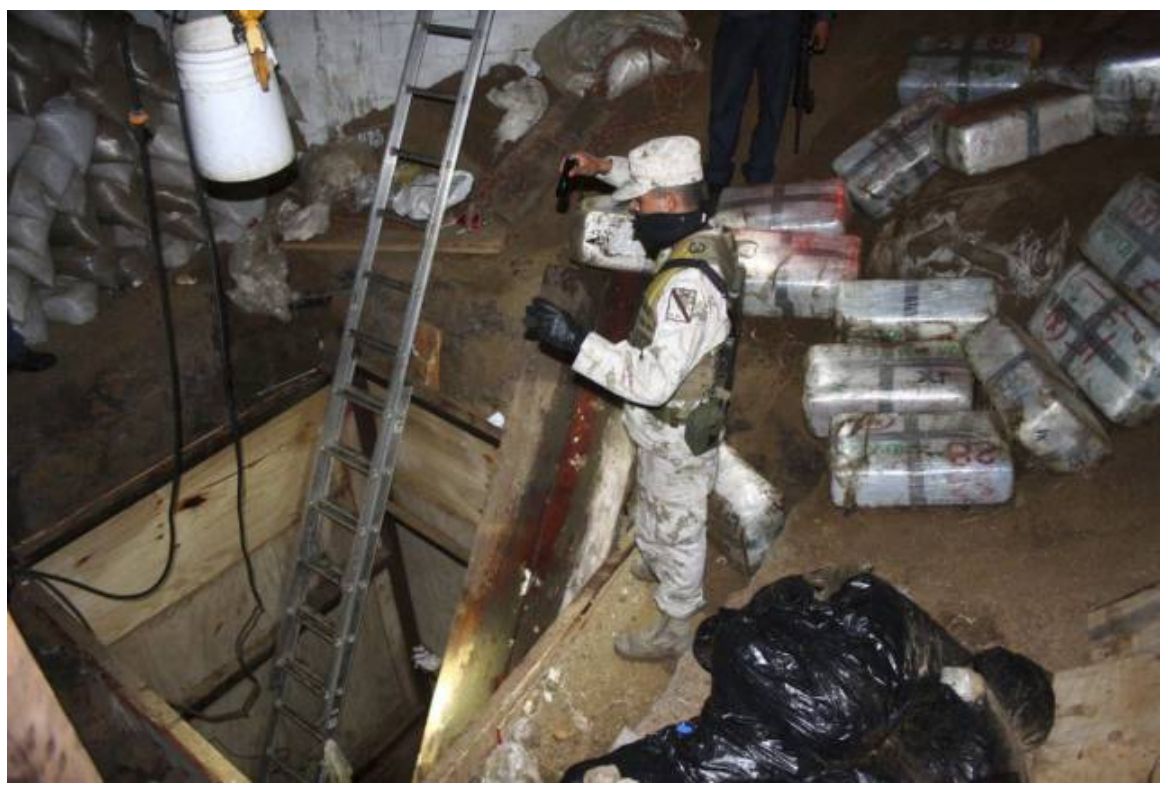

Figure 37. Soil tunnel shaft used to access a tunnel $10 \mathrm{~m}$ below the soil surface. The drug packages are lifted by a pulley system.

tunnel was seized. This is the largest tunnel cocaine seizure. The tunnel ran from a house in California to a restaurant in Mexico. This tunnel ran at a depth of 14 $\mathrm{m}$ from a hole in the ground on the American side enclosed within a fenced-in lot set up as a pallet business to the bottom of an elevator shaft built into a house in Tijuana. The hole was hidden under a trailer-sized rubbish bin that smugglers used to move the drugs. The tunnel used in the operation was sophisticated with cemented ceilings and walls and a lighting and ventilation system. On the Tijuana side (Figure 37), the tunnel was connected to an elevator that ascended into a house. Seeping drainage water, not part of a permanent water table, was periodically removed from the tunnels. 


\section{Summary and Conclusions}

Historic Native American and modern civilizations have been forcing the unstable use of the Colorado River and adjacent land resources for centuries. Much can be learned from past Native American cultures such as the Hohokam in the Colorado River watershed which can be applied to our modern civilization. Over time, soil management difficulties increased. Soils became waterlogged as a result of a lack of drainage under the irrigation systems. Sediment filled the Hohokam canals and salts accumulated in the fields reducing the soil productivity and crop yields. The adobe walls of the villages were unstable as a result of salt erosion. Salt weathering of the adobe walls resulted in their crumbling and eventual collapse and the irrigated fields were largely abandoned. Many of the modern canals overlapped or paralleled the ancient Hohokam canals. Soil salinity and erosion problems remained a threat to the stability of the modern irrigation systems. Modern technology has enabled better crop production through improved water management and effective soil drainage under the irrigation systems to remove salt from the soil profiles. The Yuma tribes farmed and hunted the floodplain of the Colorado River. The river, with an irregular flow could not be used for canal irrigation. The agricultural and urban needs in the United States are continuing to grow and it appears the days of Colorado River flowing into Mexico and the Gulf of California are numbered after declining for decades. The Colorado River is disappearing and restoration efforts appear to be too little too late. If the Colorado River valley is ever going to recover, previous lessons learned from the Native Americans, including the Hohokam, must be applied. A balanced approach to water management is needed and must include aggressive conservation and efficiency measures such as creating irrigation systems with underlying drainage systems to prevent the capillary rise of salty water to the soil surface.

If the Colorado River Valley is ever going to recover the management successes and failures learned from the Native Americans, including the Hohokam, must be applied. We could learn a lot from their previous behavior and experiences and should apply the lessons learned to the disappearing Colorado River which often runs dry. The Colorado River flow has rarely reached the Gulf of California in the last few decades. Colorado River that discharges into the Gulf of California in Mexico is over-apportioned and the river is often only a trickle at best and at times it is totally dry [17]. Most often all the water was used by ranchers, urban dwellers and farmers. The Mexico-United States boundary includes $1600 \mathrm{~km}$ of the Rio Grande and $1600 \mathrm{~km}$ of upland between El Paso and Tijuana with the Colorado River flowing across the border and through Mexico to the Gulf of California. However, in most years, the Colorado River runs dry and disappears. The United States' decision to lengthen and strengthen the existing border wall has re-ignited tensions between Mexico and the United States as the United States, attempted to reduce the flow of illegal immigrants, primarily from Central and South America. In 2021 the construction of the border wall 
has been frozen by the new Federal administration in place which has actually temporarily resulted in a reduced need by Mexico citizens and others to create and use soil tunnels under the border walls to gain illegal immigrant entry into the United States.

\section{Acknowledgements}

Published with funding (Hatch Project 875-979) and support from USDA, NIFA, Water Division and the Director of the Illinois Office of Research, College of Agricultural, Consumer, and Environmental Science, University of Illinois, Urbana, Illinois. This article is dedicated to the memory of Dr. Gerry Olson, a soil scientist and agronomist at Cornell University, who introduced the $1^{\text {st }}$ co-author to the irrigation practices of the Hohokam Indians who lived on the Gila, Salt and Colorado rivers.

\section{Conflicts of Interest}

The authors declare no conflicts of interest regarding the publication of this paper.

\section{References}

[1] Benke, A.C. and Cushing, C.E. (2005) Rivers of North America. Academic Press, Cambridge.

[2] Diaz, H.F. and Anderson, C.A. (2003) Precipitation Trends and Water Consumption in the Southwestern United States. In Impact of Climate Change and Land Use in the Southwestern United States. US Geological Survey. https://geochange.er.usgs.gov/sw/changes/natural/diaz

[3] Gelt, J. (1997) Sharing Colorado River Water: History, Public Policy and Colorado River. Compact. Water Resource Center, University of Arizona. https://learn.genetics.\%20utah.edu/content/earth.waterallocation

[4] Olson, K.R. and Speidel, D.R. (2020) Review and Analysis Successful Use of Soil Tunnels in Medieval and Modern Warfare and Smuggling. Open Journal of Soil Science, 10, 194-215. https://doi.org/10.4236/ojss.2020.105010

[5] Clausen, E. (2021) Yampa River-Colorado River Drainage Divide Origin Determined from Topographic Map Evidence, Southern Routt County, Colorado, USA. Open Journal of Geology, 11, 319-339. https://doi.org/10.4236/ojg.2021.118017

[6] Olson, G.W. (1981) Soils and the Environment. A Guide to Soil Surveys and Their Applications. Chapman and Hall, Boca Raton, Florida.

[7] Overstreet, R.M. (2015) Indian Arrowheads Identification and Price Guide. 14th Edition, Overstreet Arrowheads, LLC.

[8] Reber, R.J., Bowes, S.L., Emerson, T.E., Evans, M.G., Loebel, T.J., McElrath, D.L. and Nolan, D.J. (2017) Projectile Points and the Illinois Landscape: People, Time, and Place. University of Illinois, Illinois State Archaeological Survey. Studies in Archaeology, Number 11.

[9] Singer, S.F. and Avery, D.T. (2007) Unstoppable Global Warming: Every 1500 Years. Rowman \& Littlefield Publishers, Lanham, 46-55.

[10] Potter, L.A. and Schamel, W. (1997) The Homestead Act of 1862. Social Education, 
$61,359-364$.

[11] D’Esposito, M. (1997) Testimony before Senate Energy and Natural Resources Committee, April 28, 1998. Part of Public Domain Record. https://congress.gov/hill/105 ${ }^{\text {th }}$-congress/senate-bill/1102/text

[12] Gupta, S.K. (2010) Modern Hydrology and Sustainable Water Development. John Wiley \& Sons, Hoboken. https://doi.org/10.1002/9781444323962

[13] Legal, U.S. (2021) Prior Appropriation Doctrine Land and Legal Definition [Wyoming vs. Colorado 259. U.S. 419 (U.S. 1922)].

https://definitions.uslegal.com/p/[rior-appropriation-doctrine

[14] Cornell Law School (2021). Riparian Doctrine. Legal Information Institute. https://law.cornell.edu/wex/riparian_doctrine

[15] St. John, R. (2011) Line in the Sand. A History of the Western U.S-Mexico Border. Princeton University Press, Princeton. https://doi.org/10.23943/princeton/9780691141541.001.0001

[16] Lichtenwald, T.G. and Perri, F.S. (2013) Terrorist Use of Smuggling Tunnels. International Journal of Criminology and Sociology, 2, 210-225. https://doi.org/10.6000/1929-4409.2013.02.21

[17] Waterman, J. (2012) Where the Colorado Runs Dry. The New York Times. https://nytimes.com/2012/02/15/opinion/where-the-colorado-river-runs-dry.html 